\title{
Review \\ The Era of Nanomaterials: A Safe Solution or a Risk for Marine Environmental Pollution?
}

\author{
Maria Consiglia Esposito ${ }^{1}$, Ilaria Corsi ${ }^{2} \mathbb{D}$, Gian Luigi Russo ${ }^{1,3} \mathbb{E}^{\mathbb{D}}$, Carlo Punta ${ }^{4} \mathbb{D}$, Elisabetta Tosti $^{1}$ and \\ Alessandra Gallo 1,*(D) \\ 1 Department of Biology and Evolution of Marine Organisms, Stazione Zoologica Anton Dohrn, \\ Villa Comunale, 80121 Napoli, Italy; mariaconsiglia.esposito@szn.it (M.C.E.); glrusso@isa.cnr.it (G.L.R.); \\ elisabetta.tosti@szn.it (E.T.) \\ 2 Department of Physical, Earth and Environmental Sciences, University of Siena, Via Mattioli 4, \\ 53100 Siena, Italy; ilaria.corsi@unisi.it \\ 3 Institute of Food Sciences, National Research Council, 83100 Avellino, Italy \\ 4 Department of Chemistry, Materials, and Chemical Engineering "G. Natta", Politecnico di Milano and \\ INSTM Local Unit, Via Mancinelli 7, 20131 Milano, Italy; carlo.punta@polimi.it \\ * Correspondence: alessandra.gallo@szn.it; Tel.: +39-081-5833233
}

check for updates

Citation: Esposito, M.C.; Corsi, I.; Russo, G.L.; Punta, C.; Tosti, E.; Gallo, A. The Era of Nanomaterials: A Safe Solution or a Risk for Marine Environmental Pollution? Biomolecules 2021, 11, 441. https://doi.org/ 10.3390/biom11030441

Academic Editor: Je Yu II

Received: 9 February 2021

Accepted: 12 March 2021

Published: 16 March 2021

Publisher's Note: MDPI stays neutral with regard to jurisdictional claims in published maps and institutional affiliations.

Copyright: (c) 2021 by the authors. Licensee MDPI, Basel, Switzerland. This article is an open access article distributed under the terms and conditions of the Creative Commons Attribution (CC BY) license (https:// creativecommons.org/licenses/by/ $4.0 /)$

\begin{abstract}
In recent years, the application of engineered nanomaterials (ENMs) in environmental remediation gained increasing attention. Due to their large surface area and high reactivity, ENMs offer the potential for the efficient removal of pollutants from environmental matrices with better performances compared to conventional techniques. However, their fate and safety upon environmental application, which can be associated with their release into the environment, are largely unknown. It is essential to develop systems that can predict ENM interactions with biological systems, their overall environmental and human health impact. Until now, Life-Cycle Assessment (LCA) tools have been employed to investigate ENMs potential environmental impact, from raw material production, design and to their final disposal. However, LCA studies focused on the environmental impact of the production phase lacking information on their environmental impact deriving from in situ employment. A recently developed eco-design framework aimed to fill this knowledge gap by using ecotoxicological tools that allow the assessment of potential hazards posed by ENMs to natural ecosystems and wildlife. In the present review, we illustrate the development of the eco-design framework and review the application of ecotoxicology as a valuable strategy to develop ecosafe ENMs for environmental remediation. Furthermore, we critically describe the currently available ENMs for marine environment remediation and discuss their pros and cons in safe environmental applications together with the need to balance benefits and risks promoting an environmentally safe nanoremediation (ecosafe) for the future.
\end{abstract}

Keywords: nanomaterials; nanoremediation; marine pollution; environmental remediation; ecotoxicology; eco-design; ecosafety; ecological risk assessment

\section{Introduction}

Environmental pollution results from the rising of industrial activities and urbanization, which constantly discharge man-made wastes into the environment altering its equilibrium, integrity, and health. On daily basis, different pollutants are released into soil, atmosphere, lakes, groundwater and rivers, which in turn reach seas and oceans [1]. Consequently, as a final sink of anthropogenic pollutants, marine ecosystems are under threat and need to be restored to healthy conditions. In this scenario, nanotechnology is the science of the 21st Century that can offer the most promising devices to counteract with chemical pollution, including the marine environmental remediation. Combining physical and chemical laws, nanotechnology is able to manipulate matter generating particles on a scale of less than $100 \mathrm{~nm}$, known as engineered nanomaterials (ENMs) or nanoparticles (NPs) [2]. 
NPs can be synthesized starting from a wide variety of raw materials by applying biological, physical, or chemical methods. Based on the size of raw material, these methods include two general approaches: (i) Top-down approach starts from bulk material to create correspondingly smaller structures using finer tools; and (ii) Bottom-up approach assembles materials from the nanoscopic scale, such as molecules and atoms, to form larger structures $[3,4]$.

Protocols for ENMs/NPs synthesis are improving, promoting their environmental application that refers to "the reduction or removal of contaminants from polluted media restoring their original status" [5,6]. The use of ENMs for environmental remediation, known as nanoremediation, is more effective compared to conventional remediation approaches since nanometric materials show high reactivity, high surface-area-to-volume ratio, and a target-specific ability to capture toxic compounds [7]. Additionally, the latter approach allows a faster degradation and stabilization of contaminants by ENMs reducing the time frame and even the costs of the process [8-10]. Moreover, ENMs are more sustainable because they minimize the addition of chemicals, reduce the amount of material needed in the clean-up process [11], and potentially extend the range of available in situ remediation technologies [12,13]. Nano-sized particles are transferred into contaminated media such as soils, sediments, and aquifers by in situ remediation technology. This strategy is preferred over other approaches being more cost-effective. In most applications, zero-valent iron nanoparticles (nZVI) are successfully used to remediate groundwater, soil, wetland and river sediments [14-17]. Furthermore, the effectiveness of other ENMs for in situ remediation of soil, groundwater and sediments has been demonstrated [18-20].Therefore, application methods for in situ treatment with ENMs may also be suitable for the deployment in the marine environment.

To date, experimental studies established that ENMs can be employed to efficiently restore different marine environmental matrices [21-23], reducing the impact of toxic chemicals, thus, preserving marine biodiversity, ecosystem functioning and services. However, as such, they are applied as primary ENMs to the environment and the balance between benefits and risks associated with their use is still under debate [24,25]. Their potential release in the environment and the deriving effects on the ecosystem health become a matter of concern to be addressed. For this purpose, it is necessary to elucidate the fate and behavior of ENMs, which depend not only on their physical and chemical proprieties, but also on the characteristics of the receiving environment [26]. Of particular interest is the marine environment, which appears as a dynamic and extreme environment, due to the high ionic strength conditions, $\mathrm{pH}$, and presence of a high amount of naturally occurring particulates. Indeed, upon entry into the marine environment, ENMs undergo diverse processes, such as dissolution, transformation, speciation, agglomerate/aggregate and sedimentation, which may influence their fate and dispersion and determine the bioavailability and toxicity. These research areas need further investigation to establish a proper environmental risk assessment following an in-depth understanding of the ENMs physico-chemical properties.

Moreover, in order to achieve a "green and sustainable remediation" (GSR), it is essential to assess the risks posed by the ENMs applied to marine environment remediation techniques [27]. As a future goal of the remediation industry, environmental safety represents the main challenge for ENMs employed in marine nanoremediation and can be achieved by using environmental risk assessment approaches [24]. In such a way, the ecotoxicological testing strategy represents a fundamental aspect since it adapts the standardized ecotoxicity tests, or newly developed ones, allowing the determination of the potential impact of ENM/Ps toward different levels of biological organization, thus providing suitable toxicity data. This information will help to identify the ENMs properties that mediate the interaction with living organisms and, consequently, their toxicity, leading to the selection of the best ecofriendly and ecological sustainable ENMs [28].

In the present work, we will review the development of the eco-design framework and the application of ecotoxicology as a valuable strategy to develop ecosafe ENMs for 
environmental remediation. Furthermore, we critically describe the currently available ENMs for marine environment remediation and discuss their pros and cons in safe environmental applications together with the need to balance benefits and risks promoting a future environmentally safe nanoremediation (ecosafe).

\section{ENM/NPs and Environmental Safety}

ENMs have been identified as innovative tools to deal with the global concern of marine pollution. The best performances and higher sustainability of the ENMs, compared to macro-sized materials, are driving the progressive transition from remediation to nanoremediation. Several studies demonstrated the efficacy of ENMs in the decontamination of the marine polluted sites. However, more efforts are needed to unravel any potential environmental implication deriving from their use due to the documented toxicological outcomes on marine biota [24,28,29]. Therefore, it is crucial to develop an ecosafety strategy to protect the marine biota before the authorization of applications for in situ nanoremediation of the marine environment. A key issue in designing ENMs regards their fate after release. This aspect acquires more relevance since, once released in seawater, ENMs undergo significant transformations, which affect their behavior and toxicity on marine biota. According to the Scientific Committee on Emerging and Newly Identified Health Risks [30], chemical-physical properties of ENMs (size, surface composition, shape, solubility, aggregation, chemical reactivity) are fundamental in the risk assessment. In fact, the intrinsic characteristics of ENMs, together with the properties of the environmental matrices, are among the factors that can induce transformations of ENMs, and, consequently, affect their potential risks for human and ecosystems health [31-33]. Marine environment is an alkaline medium characterized by a high ionic strength and a wide variety of natural organic matter (NOM) [26]. ENMs can undergo dissolution into an ionic form driven by the particle chemistry, but they also rapidly co-aggregate (homoaggregation) or assemble with non-homologous particles (heteroaggregation) due to the high ionic strength and the relatively high $\mathrm{pH}$ of sea water. The ENM aggregation increases their size; consequently, the aggregates are less mobile and tend to be deposited to the sediments, becoming less available to organisms in the water column [34]. ENMs in marine water can also interact with the inorganic and organic colloidal particles, resulting in a greater stabilization effect on NPs that can influence their aggregation dynamics and colloidal stability.

The interaction between ENMs and NOM in the aquatic matrices is emerging as an attractive research field. Recently, it has been suggested that NOM produced during the algal bloom may contribute stabilize ENMs, limiting the agglomeration process [35]. However, depending on the media proprieties, the bio-nano interaction can induce an opposite mechanism, promoting agglomeration [36,37].

In some condition, the interaction of NPs with dissolved biomolecules can favor the formation of NOM-related nanoscale coatings, analogous to protein corona in mammalian systems, potentially affecting aggregation and transport of the NPs, as well as bio-distribution, uptake and toxicity to marine species [38-41]. Alternatively, NPs can be adsorbed on the exterior surface of the organism driving surface inducing toxicity. The aggregation and adsorption processes can increase the ENM concentrations in the environmental matrices. Overall, once released in the marine environment, NPs may undergo rapid transformations due to their intrinsic and extrinsic properties, which drive NP fate and determine their ecotoxicity on the marine biota [38,42]. Despite the sign of progress in the research studies of the environmental fate and behavior and risk assessment of ENMs, to date, their life cycle is characterized by a regulatory gaps, from the design and synthesis, to their usage, until the final disposal. Specific international regulation for producing, labeling, and evaluating the environmental impact of ENMs is lacking [43]. Attempting to fill these gaps, in 2007, the European Commission introduced the ENMs in the register of chemical compounds REACH (Registration, Evaluation, Authorization and Restriction of Chemicals) indicating that their safety assessment should follow the risk assessment methodology adopted for conventional chemicals. Based on the purpose 
of promoting green nanotechnology, which does not pose any risk for the environment and biota, progresses in nanoremediation are moving towards the design of eco-friendly nanosized devices with a low content of toxic substances, reduced material and energy requirements. Following this perspective, the United States Environmental Protection Agency published multiple documents as reference points, including the best management practice fact sheets for green and sustainable remediation [44]. Aiming to reduce the environmental impact of the ENMs and promote sustainable frontiers for nanoremediation, the "eco-design" approach (Figure 1) is gaining relevance.

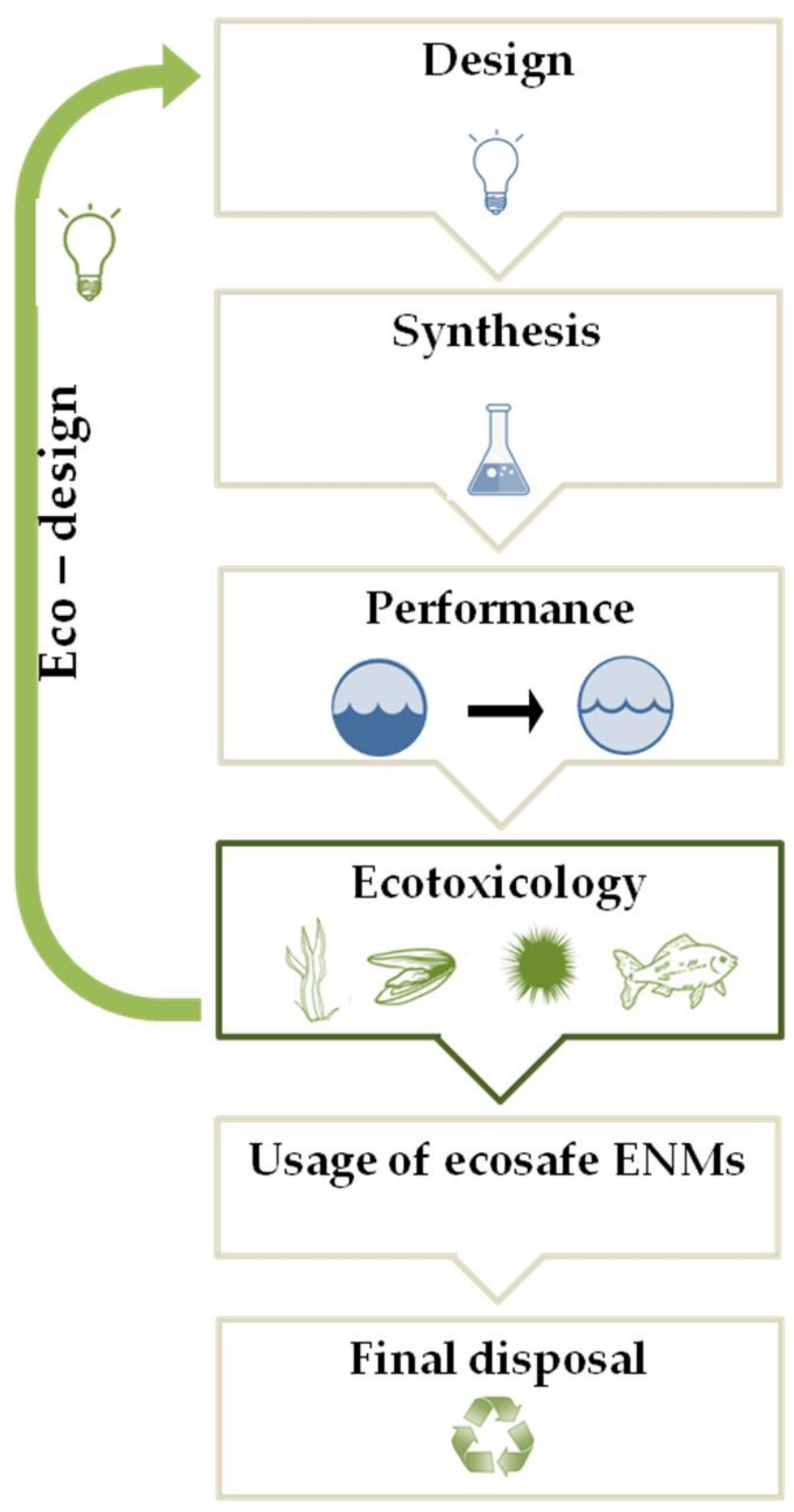

Figure 1. A schematic representation of the eco-design approach (see text for details).

This innovative approach is aimed to keep under control the environmental safety of new ENMs through the "safety-by-design" strategy (Figure 1) that results safe and sustainable in terms of ENM composition, production process, and performance. Therefore, ecotoxicology plays a key role in the "eco-design" approach in order to determine the potential risk of new synthesized ENMs for in situ nanoremediation in the marine environment $[24,45]$. The ecotoxicological assessment of ENMs can change the design and/or the 
composition of an ENM, realizing the eco-design of newly synthesized ENMs aimed at safeguarding the environment during the complete ENMs life-cycle, until their final disposal, when the nanoremediation process is over, producing recyclable and/or biodegradable ENMs, supporting the development of green nanotechnologies for marine remediation.

\section{Ecotoxicological Assessment of ENMs}

From the first evidence of ENM impact on aquatic species, nanoecotoxicology gained a relevant role in ecological risk assessment (ERA) of ENMs by recognizing how their transformations in sea water (i.e., size distribution, surface charges and bio-nano interactions) affected biological interactions and toxicological responses at population and ecosystem level $[28,29,31,46]$. Nanoscale dimension represents the main driver of cellular uptake, but exposure scenarios are affected by ENM transformations occurring in natural environments, which also identify potential target ecosystems (pelagic versus benthic) [47]. Linking exposure to the observed biological effects is a key aspect for proper ERA and bio-nano interactions are fundamental for the understanding of such complex natural exposure scenarios [28]. Eco-corona formation, as a results of particle physical-chemical interaction with dissolved biomolecules already existing in natural seawater, will affect particle uptake and related cellular pathways leading to toxicity [24,29,31,47]. To make regulatory references more suitable, a general agreement has been reached by the nanoecotox scientific community in using more realistic exposure scenarios for ERA of ENMs and in revising current standardized protocols based on bioassays $[28,33,48,49]$. Although effect-based tools including in vitro and in vivo bioassays have been successfully used to assess exposure and hazard for legacy and emerging marine pollutants, they present some limitations for ENMs [49-51]. Conversely, conventional biomarkers, such as those developed upon exposure to other toxicants (e.g., oxidative stress, lipid peroxidation, biotransformation and genotoxicity) have been successful to assess ENM effects at cellular level and identify common biological pathways, or determine toxicity [52,53]. Although not specifically modulated by ENM exposure, these biomarkers have been extremely helpful to identify cellular pathways affected by ions dissolution from NPs (i.e., AgNPs) or ENM interaction with biomolecules (i.e., DNA damage and neurotoxicity). More recently, autophagy, lysosomal dysfunction, and immunomodulation, all conserved mechanisms from invertebrates to mammals, are emerging as biomarkers for the early interactions between cells and ENMs [52-55]. Furthermore, the modern field of ecotoxicogenomics is promising in understanding the mode of action of ENMs and even in the recognition of adverse outcome pathways [56]. This will allow the identification of the first warning response upon ENM exposure and predict consequences on higher biological organization (i.e., from cell up to organs, organism and population) and marine taxa for an overall ecosystem assessment [57]. To this aim, a multi-biomarkers approach and integrate individual biomarker response indices has been proposed in order to limit any risk associated with over/underestimation of the observed biological effects [2,52,58-61].

Although standard test guidelines developed for conventional contaminants have been used to test ENMs, concerns have been raised on their appropriateness for addressing particle properties under different testing conditions and assessing the toxic effects. Due to the peculiar characteristics of ENMs, several issues must be taken into consideration including the behavior of ENMs in exposure media.

\section{ENMs Employed for Marine Environment Remediation and Their Ecosafety}

Marine environmental remediation can be achieved by different conventional methods and technologies, such as coagulation, precipitation, filtration, in situ burning of the oil spill, sediment-capping, and mechanical removal (ex situ treatments). Both the production process and the application of the traditional methods employed to clean polluted marine area need a huge amount of time, money, energy, and give rise to wastes that often cannot be regenerated. These issues can be overcome by the application of nano-based techniques, which offer more effective alternatives to traditional methods of seawater treatment. The 
ENM production processes can be simpler, limit the wasteful secondary reactions, and can reduce energy consumption with benefits for the environment and workers' health [62].

Furthermore, ENMs can remove contaminants at lower concentrations compared to the traditional methods [63]. The higher performance of nanoremediation depends on the peculiar physical-chemical properties of ENMs. These can be grafted with functional groups increasing the sensitivity, the target selectivity, the timing, and the efficiency of the nanoremediation process $[64,65]$. The higher selectivity along with the few compounds employed during the production process causes a reduction of the wastes produced after remediation treatment and boosts the reuse or the recycling of the contaminant specifically removed [66,67]. However, despite the social, economic, and environmental benefits of nanoremediation, its application is scarce due to the lack of a comprehensive assessment of the environmental risks related to ENMs.

In fact, compared to the number of different ENMs synthesized for seawater decontamination (Table 1), studies assessing the toxicity of each single ENM are scarce (Table 2). Similarly, limited interdisciplinary investigations are present in the current literature on the remediation ability of new synthetized ENMs and the ecotoxicological impact on marine organisms. This stimulate a more efficient interaction between different research fields, such as chemistry, physics, engineering, and ecotoxicology, and improved research efforts on the ecotoxicological assessment of ENMs. To obtain safe ENMs, ecotoxicological tests should mimic the real conditions before and after the nanoremediation process, taking into consideration the peculiar characteristics of ENMs, such as different sizes, structures, and shapes that contribute to the interactions with the remediation media, affecting their behavior and toxicity.

Table 1. ENMs synthetized for the remediation of marine environment.

\begin{tabular}{|c|c|c|c|c|c|c|c|}
\hline ENM & Concentration & Properties & $\begin{array}{c}\text { Target } \\
\text { Contaminants }\end{array}$ & Mechanism & Media & $\begin{array}{l}\text { Remedia- } \\
\quad \text { tion } \\
\text { Efficiency }\end{array}$ & Reference \\
\hline $\begin{array}{l}\text { Graphene oxide } \\
\text { sponge enriched } \\
\text { with florin } \\
\text { groups } \\
\text { (USTC- } \\
\text { 6@GO@sponge) }\end{array}$ & NF & $\begin{array}{l}\text { carbon-based ENM } \\
\text { with microporosity } \\
\text { and great } \\
\text { hydrophobicity for } \\
\text { the selective } \\
\text { adsorption of organic } \\
\text { compounds }\end{array}$ & $\begin{array}{c}\text { diesel oil, } \\
\text { gasoline, } \\
\text { soybean oil, } \\
\text { light petroleum, } \\
\text { n-hexane, } \\
\text { bromobenzene, } \\
\mathrm{N}^{\prime} \mathrm{N}- \\
\text { dimethylformamide } \\
\text { (DMF), } \\
\text { tetrahydrofuran, } \\
\text { acetone, } \\
\mathrm{CCl}_{4} \\
\text { methylbenzene }\end{array}$ & adsorption & seawater & NF & [68] \\
\hline $\begin{array}{l}\text { Chitosan-grafted } \\
\text { carbon } \\
\text { nanotubes } \\
\text { (CTS-g-CNTs) }\end{array}$ & $0.6 \mathrm{~g} \mathrm{~L}^{-1}$ & $\begin{array}{l}\text { external nanotube } \\
\text { diameter of } 30 \mathrm{~nm} \\
\text { and an inner } \\
\text { diameter of } 8.48 \mathrm{~nm} \text {, } \\
\text { stable in seawater }\end{array}$ & Cs & adsorption & seawater & NF & [69] \\
\hline $\begin{array}{l}\text { Graphene oxide } \\
\text { functionalized } \\
\text { with } \\
\text { polyethyleneimine } \\
\text { (GO-PEI) }\end{array}$ & $10 \mathrm{mg} \mathrm{L}^{-1}$ & $\begin{array}{c}\text { foam with three } \\
\text { dimensional porous } \\
\text { structures }\end{array}$ & $\mathrm{Hg}$ & adsorption & seawater & NF & [70] \\
\hline $\begin{array}{l}\text { Manganese- } \\
\text { ferrite NPs } \\
\left(\mathrm{MnFe}_{2} \mathrm{O}_{4}\right)\end{array}$ & $50 \mathrm{mg} \mathrm{L}^{-1}$ & $\begin{array}{l}\text { NP diameter of } 75 \pm \\
15 \text { nm; magnetism }\end{array}$ & As, $\mathrm{Pb}$ & adsorption & seawater & NF & [71-73] \\
\hline
\end{tabular}


Table 1. Cont.

\begin{tabular}{|c|c|c|c|c|c|c|c|}
\hline ENM & Concentration & Properties & $\begin{array}{c}\text { Target } \\
\text { Contaminants }\end{array}$ & Mechanism & Media & $\begin{array}{l}\text { Remedia- } \\
\quad \text { tion } \\
\text { Efficiency }\end{array}$ & Reference \\
\hline $\begin{array}{l}\text { Alginate and } \\
\text { polyvinyl alcohol } \\
\text { (PVA)-alginate } \\
\text { entrapped } \\
\text { nanoscale } \\
\text { zero-valent iron } \\
\text { (nZVI) }\end{array}$ & $\begin{array}{l}1 \mathrm{~g} \mathrm{~L}^{-1} \\
2 \mathrm{~g} \mathrm{~L}^{-1}\end{array}$ & $\begin{array}{l}\text { Particles of powder } \\
\text { average size } 50 \mathrm{~nm}\end{array}$ & $\begin{array}{l}\mathrm{Cu}, \mathrm{Zn}, \\
\mathrm{Cr}, \mathrm{As}\end{array}$ & adsorption & $\begin{array}{l}\text { saline } \\
\text { wastew- } \\
\text { ater }\end{array}$ & $\begin{array}{l}\text { Cu } 84.2 \% \\
\text { Cr } 70.8 \% ; \\
\text { Zn } 31.2 \% \\
\text { As } 39.8 \%\end{array}$ & [74] \\
\hline $\begin{array}{l}\mathrm{nFe}_{3} \mathrm{O}_{4} / \text { fly ash } \\
\text { composite }\end{array}$ & $\begin{array}{l}0.5 \mathrm{~g} \text { in } 25 \mathrm{~mL} \\
\text { of triphenylt- } \\
\text { inchloride } \\
\text { (TPT) solution }\end{array}$ & $\begin{array}{c}\mathrm{nFe}_{3} \mathrm{O}_{4} \text { size particles } \\
<50 \mathrm{~nm}\end{array}$ & $\mathrm{TPT}$ & adsorption & seawater & $98.40 \%$ & [75] \\
\hline $\begin{array}{c}\text { Potasium copper } \\
\text { hexacyanofer- } \\
\text { rate } \\
(\mathrm{KCuHCF})\end{array}$ & $0.1 \mathrm{~g} \mathrm{~L}^{-1}$ & NPs size of $10-17 \mathrm{~nm}$ & Cs & adsorption & seawater & $99 \%$ & [76] \\
\hline $\begin{array}{c}\text { Zeolitic } \\
\text { imidazolate } \\
\text { framework-8 } \\
\text { functionalized } \\
\text { with } \\
\text { ferrocyanide } \\
\text { (ZIF-8-FC) }\end{array}$ & $\begin{array}{l}\mathrm{V} / \mathrm{m}=1000 \\
\mathrm{~mL} \mathrm{~g}^{-1}\end{array}$ & $\begin{array}{l}\text { cubic particles with a } \\
\text { surface area of } \\
589 \mathrm{~m}^{2} \mathrm{~g}^{-1}\end{array}$ & Cs & adsorption & seawater & $\begin{array}{l}60 \% \text { at } 3 h \\
85 \% \text { at } 24 h\end{array}$ & [77] \\
\hline $\begin{array}{c}\text { Magnetic } \\
\text { multilayer } \\
\text { core-shell } \\
\left(\mathrm{Fe}_{3} \mathrm{O}_{4} @\right. \\
\left.\mathrm{SiO}_{2} @ \mathrm{KTiFC}\right)\end{array}$ & $\begin{array}{c}5 \mathrm{mg} \text { of } \\
\mathrm{Fe}_{3} \mathrm{O}_{4} @ \mathrm{SiO}_{2} \\
@ \mathrm{KTiFC} \\
\text { particles added } \\
\text { to } 4 \mathrm{~mL} \\
\text { seawater }\end{array}$ & $\begin{array}{l}\text { microspheres with a } \\
\text { magnetite core of } \\
300 \mathrm{~nm} ; \\
\text { magnetism }\end{array}$ & Cs & adsorption & seawater & $97.7 \%$ & [78] \\
\hline $\begin{array}{c}\text { Prussian } \\
\text { blue-embedded } \\
\text { magnetic } \\
\text { hydrogel beads } \\
\text { (PB-MHBs) }\end{array}$ & $1 \mathrm{mg} \mathrm{mL}^{-1}$ & $\begin{array}{l}\text { average size of } \\
33.8 \mathrm{~mm} ; \\
\text { magnetism }\end{array}$ & Cs & adsorption & seawater & $96.7 \%$ & [23] \\
\hline $\begin{array}{c}\text { Magnetic carbon } \\
\text { microspheres } \\
\left(\mathrm{Fe}_{3} \mathrm{O}_{4}-\mathrm{CM}\right)\end{array}$ & $5 \mathrm{~g} \mathrm{~L}^{-1}$ & $\begin{array}{c}\text { diameter } \\
\text { microspheres of } \\
\sim 30 \mu \mathrm{m} ; \\
\text { superparamagnetis }\end{array}$ & $\begin{array}{l}\text { polycyclic aromatic } \\
\text { hydrocarbons (PAH) }\end{array}$ & degradation & $\begin{array}{l}\text { marine } \\
\text { sedi- } \\
\text { ments }\end{array}$ & $87 \%$ & [79] \\
\hline $\begin{array}{c}\text { Nano- } \\
\text { hydroxyapatite } \\
\text { particles (nHAp) }\end{array}$ & $\begin{array}{c}0-10 \% \\
\text { nHAp/dry } \\
\text { weight }\end{array}$ & $\begin{array}{l}\text { rod structure with } \\
\text { dimensions of } 20 \mathrm{~nm} \\
\text { (i.d.) } \times 200 \mathrm{~nm} \\
(\text { length); } \\
\text { surface area of } \\
130 \mathrm{~m}^{2} \mathrm{~g}^{-1}\end{array}$ & $\mathrm{~Pb}, \mathrm{Cd}$ & sorption & $\begin{array}{l}\text { marine } \\
\text { sedi- } \\
\text { ments }\end{array}$ & NF & [80] \\
\hline $\begin{array}{l}\text { nZVI coated to } \\
\text { polyacrylic acid } \\
\text { (nanofer 25S) }\end{array}$ & $\begin{array}{l}\text { low }(2,3 \text { and } \\
4 \%) \text { and high } \\
(5,10 \text { and } 20 \%) \\
\text { dosages }\end{array}$ & $\begin{array}{l}\text { diameter of } 50 \mathrm{~nm} \text {; } \\
\text { total iron content of } \\
80-90 \text { wt. \%; } \\
\text { surface area of } \\
20-25 \mathrm{~m}^{2} \mathrm{~g}^{-1}\end{array}$ & $\begin{array}{c}\mathrm{Al}, \mathrm{As}, \mathrm{B}, \mathrm{Ba}, \mathrm{Co}, \mathrm{Cu}, \\
\mathrm{Ni}\end{array}$ & $\begin{array}{l}\text { adsorption, } \\
\text { reduction }\end{array}$ & $\begin{array}{l}\text { marine } \\
\text { sedi- } \\
\text { ments } \\
\text { slightly } \\
\text { polluted } \\
\text { by heavy } \\
\text { metals }\end{array}$ & $\begin{array}{c}\text { at } 3 \mathrm{~g}: \\
\text { Co } 100 \% \text {; } \\
\text { at } 4 \mathrm{~g}: \\
\text { Al } 33.3 \% \text {, } \\
\text { As } 76 \% \text {, } \\
\text { Cu } 96.8 \% \text {, } \\
\text { B } 0 \% ; \\
\text { at } 5 \mathrm{~g}: \\
\text { Al } 71.4 \% \text {, } \\
\text { Cu } 100 \%, \\
\text { As } 62 \% ; \\
\text { At } 10 \mathrm{~g}: \\
\text { B } 60.4 \% ; \\
\text { at } 20 \mathrm{~g}: \\
\text { Co } 54.3 \%\end{array}$ & [81] \\
\hline
\end{tabular}


Table 1. Cont.

\begin{tabular}{|c|c|c|c|c|c|c|c|}
\hline ENM & Concentration & Properties & $\begin{array}{c}\text { Target } \\
\text { Contaminants }\end{array}$ & Mechanism & Media & $\begin{array}{l}\text { Remedia- } \\
\quad \text { tion } \\
\text { Efficiency }\end{array}$ & Reference \\
\hline $\begin{array}{c}\text { Nanoscale zero } \\
\text { valent iron (nZVI) }\end{array}$ & $0.01-1 \mathrm{~g} / \mathrm{L}$ & $\begin{array}{l}\text { particle sizes } \\
<100 \mathrm{~nm}\end{array}$ & $\begin{array}{l}\text { polycyclic aromatic } \\
\text { hydrocarbons } \\
\text { (PAHs) }\end{array}$ & oxidation & $\begin{array}{l}\text { PAHs con- } \\
\text { taminated } \\
\text { sediments }\end{array}$ & $\begin{array}{c}70.2 \% \text { at } \\
0.01 \mathrm{~g} / \mathrm{L}, \\
78.3 \% \text { at } \\
0.1 \mathrm{~g} / \mathrm{L}, \\
86.3 \% \text { at } \\
0.5 \mathrm{~g} / \mathrm{L}, \\
78.0 \% \text { at } \\
1 \mathrm{~g} / \mathrm{L}\end{array}$ & [55] \\
\hline \multirow[b]{2}{*}{$\begin{array}{l}\text { polyvinylpyrrolidone- } \\
\text { coated magnetic } \\
\text { ENM (PVP-Fe }{ }_{3} \mathrm{O}_{4} \\
\mathrm{NMs})\end{array}$} & $167 \mathrm{mg} / \mathrm{L}$ & \multirow[b]{2}{*}{$\begin{array}{l}\text { median size of } \\
11.2 \mathrm{~nm}\end{array}$} & $\mathrm{~Pb}, \mathrm{Cr}, \mathrm{Ni}, \mathrm{Cd}$ & \multirow[b]{2}{*}{ adsorption } & \multirow[b]{2}{*}{ seawater } & $\begin{array}{l}\mathrm{Pb} 100 \% \\
\mathrm{Cr} 98.8 \% \\
\mathrm{Ni} 60-70 \% \\
\mathrm{Cd} 40-50 \%\end{array}$ & [82] \\
\hline & $375 \pm 10 \mathrm{mg} / \mathrm{L}$ & & oil-water mixtures & & & $\begin{array}{l}70 \% \text { of } \\
\text { lower- } \\
\text { chain } \\
\text { alkanes } \\
\text { (C9-C22); } \\
65 \% \text { of } \\
\text { higher- } \\
\text { chain } \\
\text { (C23-C26), }\end{array}$ & [83] \\
\hline $\begin{array}{l}\text { Starch-based } \\
\text { nanosponges }\end{array}$ & $12 \mathrm{mg}$ in $15 \mathrm{~mL}$ & $\begin{array}{c}\text { citrate } \\
\text { nanosponges with } \\
\beta \text {-cyclodextrin } \\
(\beta-C D) \text { or } \\
{ }^{\circledR} \text { linecaps }\left({ }^{\circledR} \mathrm{LC}\right) \\
\text { scaffold } \\
\text { pyromellitic } \\
\text { nanosponges with } \\
\beta \text {-cyclodextrin } \\
(\beta-C D) \text { or } \\
{ }^{\circledR} \text { linecaps }\left({ }^{\circledR} \mathrm{LC}\right) \\
\text { scaffold }\end{array}$ & $\mathrm{Cu}, \mathrm{Zn}$ & adsorption & seawater & $\begin{array}{c}\mathrm{Cu} \\
36-45 \% \\
\mathrm{Zn}<60 \%\end{array}$ & [84] \\
\hline $\begin{array}{c}\text { Powder of } \\
\text { Cellulose-Based } \\
\text { Nanostructured } \\
\text { Sponges (CNS) }\end{array}$ & $0.8 \mathrm{mg} \mathrm{mL}^{-1}$ & $\begin{array}{l}\text { particle size range } \\
50 \text { to } 400 \mu \mathrm{m}\end{array}$ & $\mathrm{Zn}, \mathrm{Cu}, \mathrm{Cr}, \mathrm{Cd}$ & adsorption & seawater & $90 \%$ & {$[45,85,86]$} \\
\hline $\begin{array}{l}\text { KCuHCF-cellulose } \\
\text { hydrogel }\end{array}$ & $10 \mathrm{mg}$ in $20 \mathrm{~mL}$ & $\begin{array}{l}\text { Cubic-shaped } \\
\text { particles of } \\
10-12 \mathrm{~nm}\end{array}$ & Cs & adsorption & seawater & $>90 \%$ & [87] \\
\hline $\begin{array}{c}\mathrm{PB} \text { coating } \mathrm{Fe}_{3} \mathrm{O}_{4} \\
\mathrm{NPs} \text { anchored to the } \\
\text { surface of the GO } \\
\text { sheets } \\
\left(\mathrm{PB} / \mathrm{Fe}_{3} \mathrm{O}_{4} / \mathrm{GO}\right)\end{array}$ & $\begin{array}{l}0.05 \mathrm{~g} \text { of NPs } \\
\text { in } 30 \mathrm{~mL}\end{array}$ & $\begin{array}{c}\text { average size of } 17 \\
\text { nm;magnetism }\end{array}$ & Cs & adsorption & seawater & $52.19 \%$ & [88] \\
\hline
\end{tabular}

NF: data not found.

Based on their main chemical compositions, ENMs used for marine environment nanoremediation can be broadly grouped as: (i) Metal oxides based nanomaterials (the most abundant class, 37\%); (ii) magnetic-core nanocomposites (21\%); (iii) carbon-based and polysaccharides-based nanostructured materials employed at the same percentage (16\%); (iv) hybrid nanomaterials, the less employed for marine clean-up (10\%) (Figure 2). 
Table 2. Ecotoxicological assessment of ENMs synthetized for the remediation of marine environment.

\begin{tabular}{|c|c|c|c|c|c|c|}
\hline ENM & $\begin{array}{l}\text { Concentra- } \\
\text { tion }\end{array}$ & Properties & $\begin{array}{l}\text { Experimental } \\
\text { Conditions }\end{array}$ & Species & Effects & Reference \\
\hline $\begin{array}{c}\text { manganese- } \\
\text { ferrite NPs } \\
\left(\mathrm{MnFe}_{2} \mathrm{O}_{4} \mathrm{NPs}\right)\end{array}$ & $50 \mathrm{mg} / \mathrm{L}$ & $\begin{array}{l}\text { NPs size of } \\
75 \pm 15 \mathrm{~nm}\end{array}$ & $\begin{array}{l}24 \text { h exposure in ASW } \\
\left(\mathrm{T} 17.0 \pm 1.0^{\circ} \mathrm{C} ;\right. \\
\text { pH } 8.0 \pm 0.1 ; \text { salinity } \\
30 \pm 1 ; \text { photoperiod } \\
\text { light/dark } 12 \text { h: } 12 \mathrm{~h} ; \\
\text { continuous aeration) }\end{array}$ & $\begin{array}{c}\text { Mytilus } \\
\text { galloprovincialis }\end{array}$ & $\begin{array}{c}\text { enhancement of } \\
\text { antioxidant and } \\
\text { biotransformation } \\
\text { enzymes activities; } \\
\text { lipids and protein } \\
\text { damages; } \\
\text { neurotoxicity }\end{array}$ & [73] \\
\hline $\begin{array}{c}\text { manganese- } \\
\text { ferrite NPs } \\
\left(\mathrm{MnFe}_{2} \mathrm{O}_{4} \mathrm{NPs}\right)\end{array}$ & $50 \mathrm{mg} / \mathrm{L}$ & $\begin{array}{c}\text { NPs size } \\
75 \pm 15 \mathrm{~nm}\end{array}$ & $\begin{array}{c}28 \text { days' exposure } \\
\text { in ASW } \\
\left(\mathrm{T} 17.0 \pm 1.0^{\circ} \mathrm{C} ;\right. \\
\mathrm{pH} 8.0 \pm 0.1 ; \text { salinity } \\
30 \pm 1 ; \text { photoperiod } \\
\text { light/dark } 12 \mathrm{~h}: 12 \mathrm{~h} ; \\
\text { continuous aeration) }\end{array}$ & $\begin{array}{l}\text { Mytilus } \\
\text { galloprovincialis }\end{array}$ & $\begin{array}{l}\text { depression of metabolic } \\
\text { activity, oxidative stress, } \\
\text { cellular membrane } \\
\text { damage, neurotoxicity }\end{array}$ & [72] \\
\hline GO-PEI & $10 \mathrm{mg} / \mathrm{L}$ & $\begin{array}{l}\text { foam with three } \\
\text { dimensional } \\
\text { porous structures }\end{array}$ & $\begin{array}{c}28 \text { days' exposure } \\
\text { in ASW } \\
\left(\mathrm{T} 17.0 \pm 1.0{ }^{\circ} \mathrm{C} ;\right. \\
\mathrm{pH} 8.0 \pm 0.1 ; \text { salinity } \\
30 \pm 1 ; \text { photoperiod } \\
\text { light/dark } 12 \mathrm{~h}: 12 \mathrm{~h} ; \\
\text { continuous aeration) }\end{array}$ & $\begin{array}{l}\text { Mytilus } \\
\text { galloprovincialis }\end{array}$ & $\begin{array}{l}\text { depression of metabolic } \\
\text { activity, oxidative stress, } \\
\text { cellular membrane } \\
\text { damage, neurotoxicity } \\
\text { necrosis and apoptosis } \\
\text { in female gonads, } \\
\text { cellular atrophy in } \\
\text { digestive tubules }\end{array}$ & {$[70]$} \\
\hline GO-PEI & $10 \mathrm{mg} / \mathrm{L}$ & $\begin{array}{l}\text { foam with three } \\
\text { dimensional } \\
\text { porous structures }\end{array}$ & $\begin{array}{c}28 \text { days exposure } \\
\text { in ASW } \\
\left(\mathrm{T} 17.0 \pm 1.0^{\circ} \mathrm{C} ;\right. \\
\text { pH } 8.0 \pm 0.1 ; \text { salinity } \\
30 \pm 1 ; \\
\text { continuous aeration })\end{array}$ & $\begin{array}{c}\text { Ruditapes } \\
\text { philippinarum }\end{array}$ & $\begin{array}{l}\text { depression of metabolic } \\
\text { activity, oxidative stress, } \\
\text { cellular membrane } \\
\text { damage; } \\
\text { alteration in gills and in } \\
\text { digestive tubules }\end{array}$ & {$[71]$} \\
\hline CNS & $1.25 \mathrm{~g} / \mathrm{L}$ & $\begin{array}{c}\text { powder of } \\
\text { cellulose-based } \\
\text { nanostructured } \\
\text { sponges with } \\
\text { particle size range } \\
\text { of } 50 \text { to } 400 \mu \mathrm{m}\end{array}$ & $\begin{array}{c}48 \mathrm{~h} \text { of exposure in ASW } \\
\left(\mathrm{T} 18 \pm 1{ }^{\circ} \mathrm{C} ;\right. \\
\text { pH } 8 \pm 0.1 ; \text { salinity } \\
40 \pm 1)\end{array}$ & $\begin{array}{c}\text { Mytilus } \\
\text { galloprovincialis }\end{array}$ & $\begin{array}{l}\text { none in immune and } \\
\text { gill cells and mantle }\end{array}$ & [89] \\
\hline \multirow{3}{*}{ Nanofer25S } & $\begin{array}{c}1.25 \mathrm{~g} / \mathrm{L} \\
\text { serial } \\
\text { diluitions } \\
(1: 20,1: 10 \\
1: 5,1: 2 \\
\text { undiluited })\end{array}$ & & $\begin{array}{c}72 \mathrm{~h} \text { of exposure in ASW } \\
\text { initial density of } \\
10^{4} \text { cells } \mathrm{m} / \mathrm{L}\end{array}$ & $\begin{array}{l}\text { Dunaliella } \\
\text { tertiolecta }\end{array}$ & $\begin{array}{l}\text { algal growth inhibition } \\
\text { with undiluited CNS }\end{array}$ & [45] \\
\hline & $\begin{array}{c}0.01- \\
100 \mathrm{mg} / \mathrm{L}\end{array}$ & $\begin{array}{c}\text { commercial } \\
\text { nanoscale } \\
\text { zero-valent iron } \\
\text { NPs with a size of } \\
80-120 \mathrm{~nm}\end{array}$ & $\begin{array}{l}96 \mathrm{~h} \text { of exposure in } \\
\text { NSW (pH } 8.1,20^{\circ} \mathrm{C} \text {, } \\
\text { salinity } 34 \text {; light:dark } \\
\text { cycle } 14: 10) \text { initial } \\
\text { density of } 1-2 \\
\times 10^{5} \text { cells } \mathrm{mL}^{-1}\end{array}$ & $\begin{array}{l}\text { Isochrysis } \\
\text { galbana } \\
\text { Dunaliella } \\
\text { tertiolecta } \\
\text { Thalassiosira } \\
\text { pseudonana }\end{array}$ & $\begin{array}{c}\text { algal growth } \\
\text { inhibition at: } \\
3.1 \mathrm{mg} / \mathrm{L} \text { for I. galbana; } \\
1.3 \mathrm{mg} / \mathrm{L} \text { for } \\
\text { D. tertiolecta; } \\
\text { 0.4 mg/L for } \\
\text { T. pseudonana }\end{array}$ & [90] \\
\hline & $1.8-10 \mathrm{mg} / \mathrm{L}$ & $\begin{array}{l}\text { commercial } \\
\text { nanoscale } \\
\text { zero-valent iron } \\
\text { NPs size } \\
80-120 \mathrm{~nm}\end{array}$ & $\begin{array}{c}2 \text { h gamete exposure } \\
\text { (T } 0.5^{\circ} \mathrm{C}, \mathrm{pH} 8.1 ; \\
\text { salinity } 35.1 \pm 0.52, \text { for } \\
\text { sea urchins and mussels; } \\
\mathrm{T} 17 \pm 0.1^{\circ} \mathrm{C} \text {, salinity } \\
36 \pm 0.02 \text {, for } \\
\text { sea squirts) } \\
\text { egg: sperm ratio } \\
1: 1 \times 10^{6}\end{array}$ & $\begin{array}{l}\text { Spermatozoa of } \\
\text { Mytilus } \\
\text { galloprovincialis, } \\
\text { Ciona intestinalis } \\
\text { and } \\
\text { Psammechinus } \\
\text { milliaris }\end{array}$ & $\begin{array}{c}\text { fertilization } \\
\text { success decrease; } \\
\text { embryo } \\
\text { development delay }\end{array}$ & [91] \\
\hline nano- $\mathrm{Fe}_{2} \mathrm{O}_{3}$ & $\begin{array}{c}0 ; 100 ; 1000 ; \\
10,000 \mu \mathrm{g} / \mathrm{L}\end{array}$ & size of $50 \mathrm{~nm}$ & $\begin{array}{c}\text { NSW } \\
\left(\mathrm{T} 15 \pm 0.5^{\circ} \mathrm{C} ; \mathrm{pH} 8.1\right. \\
\text { salinity } 35.1 \pm 0.52)\end{array}$ & $\begin{array}{c}\text { Mytilus } \\
\text { galloprovincialis }\end{array}$ & $\begin{array}{l}\text { None on embryo } \\
\text { development }\end{array}$ & [92] \\
\hline $\mathrm{PVP}-\mathrm{Fe}_{3} \mathrm{O}_{4} \mathrm{NMs}$ & 0-100 mg/L & $\begin{array}{l}\text { median size of } \\
11.2 \mathrm{~nm}\end{array}$ & $\begin{array}{c}96 \mathrm{~h} \text { exposure in ASW } \\
\text { (T } 25 \pm 1^{\circ} \mathrm{C} \text {; salinity } 30 \text { ) }\end{array}$ & $\begin{array}{l}\text { Amphiascus } \\
\text { tenuiremis }\end{array}$ & $\begin{array}{c}\text { None on copepod } \\
\text { mortality up to } 25 \mathrm{mg} / \mathrm{L}\end{array}$ & [93] \\
\hline
\end{tabular}




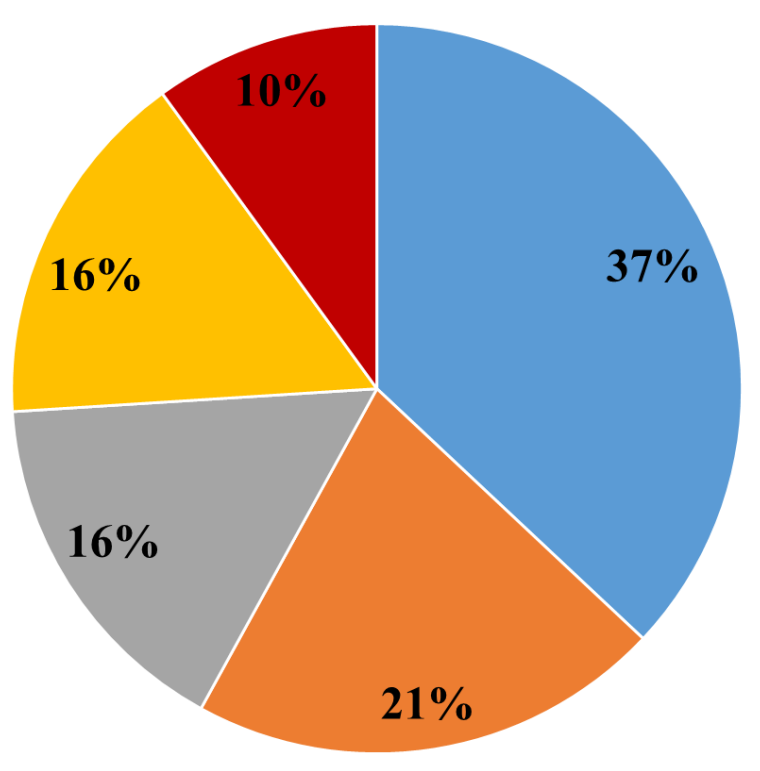

- Metals and metal oxides

\section{- Magnetic-core} nanocomposites

Polysaccharides-based nanostructured materials

\section{Carbon-based nanostructured materials}

- Hybrid nanomaterials

Figure 2. Classes of ENMs employed for marine environment nanoremediation.

In the following sections, we describe the characteristics of these classes of ENMs designed for marine nanoremediation and their ecotoxicological assessment, when available, using the marine organisms belonging to the classification reported in Figure 3, and the exposure conditions mimicking the marine environment.

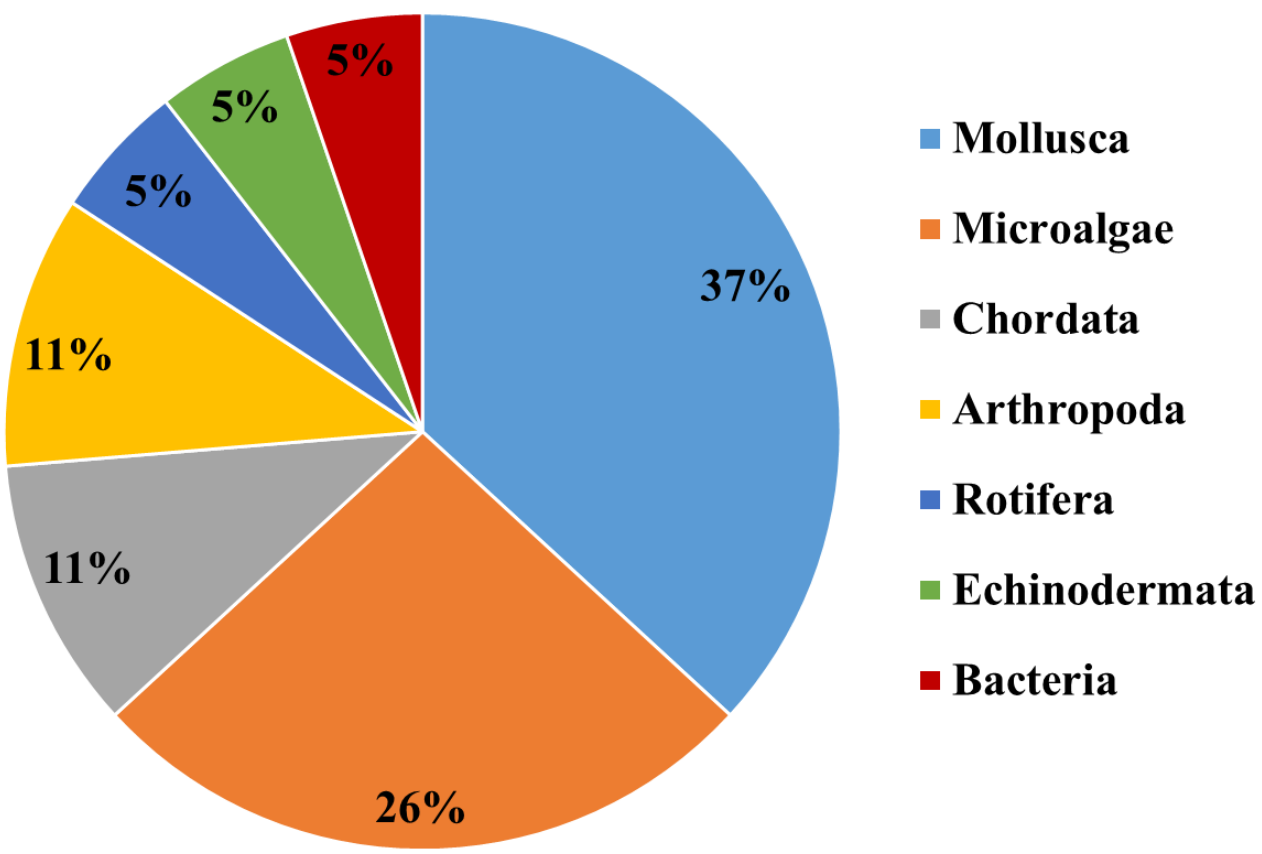

Figure 3. Marine organisms employed for ecotoxicological assessment of ENMs in marine remediation applications belong to the Kingdoms and Phyla indicated in the pie chart (see text for details). 


\subsection{Metal and Metal Oxides Based Nanomaterials}

Metals are widely employed as base materials to produce ENMs. In fact, metalbased ENMs are characterized by a good capacity in removing heavy metals and organic pollutants from water due to their fast kinetics and high adsorption efficiency [94].

Adsorption is a mechanism broadly used both in traditional remediation approaches and nanoremediation for treating contaminated seawater. For instance, since 2013, the adsorbent capacity of functionalized ferrite NPs has been investigated for $\mathrm{Pb}$ and $\mathrm{Hg}$ removal from seawater $[72,95]$. Nowadays, the latest advancement in the application of ferrite oxides for marine nanoremediation is focused on manganese-ferrite NP as a good adsorbent material [96]. Recently, Coppola and co-workers explored the use of manganese-ferrite NP $\left(\mathrm{MnFe}_{2} \mathrm{O}_{4}-\mathrm{NPs}\right.$, produced by the oxidative hydrolysis of ferrous sulfate heptahydrate and manganese sulfate in alkaline conditions) to remediate seawater from As and $\mathrm{Pb}[72,73]$. Despite their efficiency for metal remediation in seawater, these ENMs have been demonstrated to negatively affect marine bivalve species (Mytilus galloprovincialis, Ruditapes philippinarum) causing a reduction of the metabolic activity and a gain of antioxidant defenses, neurotoxicity, and oxidative stress [71-73]. Further studies are necessary on marine organisms of different trophic levels to assess the safety of $\mathrm{MnFe}_{2} \mathrm{O}_{4}-\mathrm{NPs}$ for in situ marine remediation application.

The zero valent nanomaterials (nZVs) have been considered as promising ENMs for environmental remediation being high reactivate in adsorbing and degrading different contaminants. nZVs have been synthesized from various naturally reducing agents and are able to transform organic (trichloroethane, trinitrotoluene, pesticides, dyes), or inorganic contaminants (heavy metals and inorganic anions) into less harmful or harmless substances [97]. Nanoscale zero-valent iron (nZVI) is one of the main candidates for environmental nanoremediation, being able to replace organic and inorganic pollutants in the environment using iron widely distributed in nature $[98,99]$. Compared to iron particles, nZVI possesses several advantage, such as a fast kinetics, high reactivity, high removal capacity, and the possibility to be injected directly into a contaminated site due to its proprieties, such as small particle size, high surface-area-to-volume ratio, magnetism [100]. The latter represents a useful property for water treatment systems since it does not provide attractive magnetic forces between nanoparticles and allows separation and recovery of magnetic nanoparticles from solution to be reused applying methods that are cost effective, i.e., a magnetic field or a hand-held magnet [101]. Nevertheless, further researches are needed to better understand the potential application and the environmental risk of nZVI. In fact, to date, only a few studies assessed the toxicity of nZVI in marine organisms. In particular, nZVI has been demonstrated to cause a decrease in the growth rates in three species of phytoplankton [74] and a delay in embryo development in three free spawning invertebrates (M. galloprovincialis, Ciona intestinalis, and Psammechinus milliaris) [91,92].

Nano-iron oxide $\left(\mathrm{nFe}_{3} \mathrm{O}_{4}\right)$ and $\mathrm{nFe}_{3} \mathrm{O}_{4} /$ fly ash composites have been investigated to remediate contaminated seawater from triphenyltin chloride (TPT), an organotin compound employed as pesticides and fungicides. Their adsorption efficiency was examined at different $\mathrm{pH}$, temperature, and mass of adsorbent nanocomposite employed and tested on seawater collected from a contaminated harbor. The functionalized $\mathrm{Fe}_{3} \mathrm{O}_{4}$ with fly ash nanocomposite revealed a higher ability to remove TPT compared to $\mathrm{nFe}_{3} \mathrm{O}_{4}$ [75]. However, the ecotoxicological assessment of such ENMs has not been yet performed.

Titanium dioxide NP $\left(\mathrm{nTiO}_{2}\right)$ has gained considerable attention in marine environmental remediation as an efficient catalyst and adsorbent of organic contaminants and heavy metals. The toxicity of $\mathrm{nTiO}_{2}$ in marine species has been extensively tested in invertebrates and fishes, as well as in marine mammals. In the mollusk abalone (Haliotis diversicolor supertexta), $\mathrm{nTiO}_{2}$ affected embryo development causing hatching inhibition and malformations [102]. In the mussel M. galloprovincialis, $\mathrm{nTiO}_{2}$ exposures induced $\mathrm{Ti}$ accumulation in a tissue-specific manner, histomorphological and histochemical alterations in gills and digestive gland, and DNA damage in hemocytes [103]. Furthermore, it causes a chromosomal alteration in peripheral erythrocytes in the European sea bass Dicentrarchus 
labrax [104] and DNA damage in bottlenose dolphin (Tursiops truncatus) leukocytes [105]. On the contrary, $\mathrm{nTiO}_{2}$ particles with a size of $25 \mathrm{~nm}$ have been reported to be non-toxic for the bacteria Vibrio fischeri, crustaceans and rotifers (Artemia salina and Brachionus plicatilis), suggesting a minimal risk for marine organisms when used for remediation purpose [106].

Only recently, ecosafety of silver NPs (AgNPs) bifunctionalized with hydrophilic capping agents as citrate (Cit) and L-cysteine (L-cys), developed as sensor of mercury but also able to remove it from polluted waters, have been demonstrated [107]. Exposure of two microalgae, the marine Phaeodactylum tricornutum and the freshwater Raphidocelis subcapitata to increasing concentrations $(10-500 \mu \mathrm{g} / \mathrm{L})$ of AgNPs coated with Cit and L-cys showed no effects on algal growth, supporting the protective role of capping agents in preventing the release of $\mathrm{Ag}$ ions from the NP in both freshwater and seawater media. This study confirmed the absence of risks associated with AgNPs future environmental applications as sensor for $\mathrm{Hg}$ and for its removal [107]. AgNPs ecotoxicity has been largely documented both in terrestrial and aquatic environments and on various taxa from bacteria to fish including mammalian cell lines [38,108-112]. The release of $\mathrm{Ag}^{+}$from dissolved NPs in exposure media has been recognized as a driver to explain the observed toxicity; however, a nanoparticle-based effect has been also reported [50-52,54,58,113,114]. Therefore, an ecosafety assessment of AgNPs for environmental applications is mandatory and can be achieved using bioassays as suitable tools to support their use in situ.

Similarly, nanomaterials based on hexacyanoferrate (HCF), a dark blue pigment also named Prussian Blue (PB), have been examined for the remediation of cesium (Cs) polluted seawater [115-117]. In particular, copper hexacyanoferrate (CuHCF) NPs containing $\mathrm{K}^{+}$ ions (KCuHCF-NPs) show chemical stability in artificial seawater and high efficiency and sensitivity; furthermore, they can be easily recovered from seawater by filtration, after the coagulation-precipitation method [76]. The last advancement in seawater remediation from radioactive Cs is represented by the zeolitic imidazolate framework (ZIF-8) functionalized by ferrocyanide (FC). The adsorption ability of ZIF-8-FC has been tested at various $\mathrm{pH}$ and temperatures and an excellent $\mathrm{Cs}^{+}$selectivity has been demonstrated in artificial seawater (ASW) [77]. However, to date, the absence of toxicity on marine organisms represents a limitation for a safe environmental application.

\subsection{Magnetic-Core Nanocomposites}

Magnetic particles are particularly attractive due to their superparamagnetic nature and unique physical-chemical properties, such as high dispersibility, relatively large surface area, and the high ratio of surface to volume resulting in a higher adsorption capacity. They are characterized by a shell with a core, which consists of magnetic elements such as iron, nickel, cobalt, or their oxides [118]. Among them, polyvinylpyrrolidone (PVP)coated iron oxide NMs have demonstrated to be able to remediate seawater from different metals and oils [82]. Furthermore, the oil removal efficiency of these magnetic NMs can be increased combining their activity with oil-degrading bacteria [83]. This finding underlines the possibility of a merged application that includes nanoremediation and microbial bioremediation for in situ treatments. The acute toxicity of $\mathrm{PVP}-\mathrm{Fe}_{3} \mathrm{O}_{4} \mathrm{NMs}$ has been tested in the copepod Amphiascus tenuiremis demonstrating that the optimal concentration for oil removal did not affect copepod survival [93]. However, the toxicity of the optimal concentration for metal removal and the chronic toxicity have not been yet evaluated. PVP-coatedFe $\mathrm{O}_{4}$ NMs can be produced by a simple and cost-effective method of hydrothermal synthesis, which requires no organic solvents, low toxic reactants, and low temperature/energy $[93,119]$. This feature, along with the demonstrated effectiveness at the lab-scale and the absence of acute toxicity, encourages future experiments at a larger scale and an ecotoxicological assessment that includes different levels of biological organization and chronic exposure.

The removal of radioactive $\mathrm{Cs}^{+}$from seawater was also investigated in a study where researchers synthesized core-shell multilayer magnetic microspheres [78]. The $\mathrm{Fe}_{3} \mathrm{O}_{4} @ \mathrm{SiO}_{2} @ \mathrm{KTiFC}$ magnetic microparticles demonstrated removal efficiency in different 
natural seawater conditions and high selectivity for $\mathrm{Cs}^{+}$and other ions, such as $\mathrm{Na}^{+}, \mathrm{Ni}^{2+}$, $\mathrm{Fe}^{3+}, \mathrm{Sr}^{2+}, \mathrm{Mo}^{6+}, \mathrm{Zr}^{4+}, \mathrm{Ba}^{2+}$, and $\mathrm{Nd}^{4+}$ supporting their application in the decontamination of $\mathrm{Cs}^{+}$radioactive seawater, even if, to date, their ecotoxicity remains unexplored.

The latest progress in the treatment of Cs-contaminated seawater underline the role of the Prussian blue-embedded magnetic hydrogel beads (PBMHBs) as recoverable adsorbent [23]. PB presents a high selectivity for radioactive Cs, which confers to these beads a high efficiency in removing it from seawater. Among the benefits of PBMHBs, it can be mentioned the eco-friendly and simple one-step protocol developed to encapsulate PB in MHBs and the low cost for possible large-scale treatment of Cs-contaminated water. Moreover, the ability of nanosized PB to act as ROS scavengers has been demonstrated by in vitro studies that support the possible ecosafety of this nanomaterial [120]. However, to our knowledge, no studies have been published on its impact on marine biota.

Magnetic carbon microspheres (CMs) coated with $\mathrm{nFe}_{3} \mathrm{O}_{4}$ have been used to efficiently degrade polycyclic aromatic hydrocarbons $(\mathrm{PAH})$ from contaminated marine sediments, from which they can be easily recycled since $\mathrm{CMs}$ exhibit an excellent response to a magnetic field [79]. For these ENMs, to date, the potential impact on marine biota is unknown.

\subsection{Hybrid Nanocomposites}

Carbon-based ENMs are giving a significant contribution to the development of functional and suitable materials for marine remediation. They are characterized by a scaffold of carbon atoms that can assume different three-dimensional structures generating fullerene, carbon nanotubes (CNTs), graphene, and graphite. Many decades have passed since, in 1985, the chemists Kroto and colleagues casually discovered a spherical structure of 60 carbon atoms [121]. Fullerene is characterized by peculiar properties, such as chemical stability, high electron affinity and high surface to volume ratio, which make it a useful nanomaterial to be applied in the production of nanofiltration (NF) membranes [122]. Indeed, compared to the microporous membrane, NF carbon-based membranes are characterized by smaller pores, which enhance their permeability to water and gas making them a promising tool for seawater clean-up [123]. Moreover, some NF membranes exhibit an antifouling ability, which promotes their longer life-span, reducing the energy consumption of the remediation process. Whereas, the apolar and hydrophobic character of fullerene can facilitate ENM recovery after remediation. Currently, most NF membranes are thin-film composites (TFC), and their ability to selectively separate ion metals $\left(\mathrm{Li}^{+}, \mathrm{Mg}^{2+}, \mathrm{Pb}^{2+}, \mathrm{Cd}^{2+}, \mathrm{Zn}^{2+}\right.$, and $\mathrm{Ni}^{2+}$ ) from aqueous media has been widely investigated [124,125]; however, to date, it has been synthesized only one membrane that exhibited a high $\mathrm{Mg}^{2+} / \mathrm{Li}^{+}$separation factor suggesting its potential application in treatment of Li contaminated seawater [22]. CNTs are one-dimensional fibrous nanomaterials formed by a single or multiple rolled layer, which assumes the structure of a hollow and cylindrical tube [126]. They can be easily functionalized for a specific filtration or sorption of inorganic contaminants from seawater and their adsorption efficiency is $\mathrm{pH}$-dependent [127]. CNTs have been also developed to treat spilled oil. Oil run-off from offshore platforms or accidental tanker spills results in the formation of a sticky crude oil layer on the sea surface [128]. The addition of dispersants to facilitate the dispersion of the floating oil layer into smaller droplets is a traditional method for mitigating oil spill impacts, but the majority of dispersants are toxic to humans and aquatic species. Trying to obtain a green oil spill clean-up, different complementary studies are moving toward the synthesis of dispersant-free ENMs or ENMs with a lower content of dispersants. Surfactant-loaded halloysite nanotubes (HNTs) show the potentiality to replace traditional liquid dispersant formulations enhancing marine oil spill remediation [129-131]. Other cheap and environmentally sustainable alternatives to face oil spill clean-up are the three-dimensional (3D) aerogels and carbon-based sponges that can be obtained through different procedures [132-134]. Compared with traditional sorbents, the resulting 3D materials exhibit a larger oil sorption capacity, high hydrophobicity and oleophilicity, mechanical stability, large surface areas and are reusable and /or recyclable [135-139]. Recently, modified extended graphene (M-EG) with cetyl trimethyl 
ammonium bromide $(\mathrm{CTAB})$ and potassium bromide $(\mathrm{KBr})$ has been synthesized and demonstrated to be efficient in removing different oils from seawater at different sodium salt concentrations. However, its adsorption ability was affected by temperature [140]; finally, its capacity to be regenerated several times by filtration-drying cycles, without altering its adsorption performance, makes it an ideal candidate for treating marine oil pollution in practical application. Jiang et al. [68] designed a graphene oxide (GO) sponge enriched with florin groups which enhance the sponge hydrophobicity preventing the entry of water into the pores. The hierarchically porous sorbent material is able to adsorb organic solvents and various oils and to retain its adsorption efficiency for a long time, reducing time and materials consumption of the oil recovery process. An additional material employed for marine environmental remediation is the graphene oxide chitosan-based (GO-CH-based). It is a hydrogel with a 3D macrostructure developed taking advantage of the ability of GO to self-assembly in presence of the natural biopolymer such as chitosan [141,142]. Chitosan is a non-toxic and hydrophilic compound deriving from the alkaline deacetylation of chitin, which boosts the adsorption ability of the hydrogel. Nevertheless, GO-CH nanocomposites was not efficient in removing $\mathrm{Hg}$ from seawater [141]. On the other hand, chitosan-grafted carbon nanotubes (CTS-g-CNTs) are gaining more attention as a viable material to remedy contaminated seawater from radioactive $\mathrm{C}$. The higher presence of $-\mathrm{OH}$ functional groups, related to the grafted chitosan, increases the interaction with $\mathrm{Cs}^{+}$ions and the removal efficiency, which is $\mathrm{pH}$-dependent and relies on the presence of the competitive cations [69]. The literature herein reviewed provides the high efficiency of this class of ENMs in seawater remediation; but, on the other hand, it does not face the issue of ecotoxicological assessment, posing a limit for their application in real scenarios.

An exception is represented by the GO functionalized with polyethyleneimine (GO$\mathrm{PEI})$, which is able to decontaminate seawater from $\mathrm{Hg}$. Indeed, the toxic impact of this nanostructured material has been evaluated in mussel (M. galloprovincialis) resulting in necrosis and apoptosis in mature oocytes and histopathological damages in the digestive tubules [70].

\subsection{Polysaccharides-Based Nanostructured Materials}

Carbohydrates (e.g., starch, cellulose, glycogen) are gaining the attention of researchers to produce innovative and ecosafe nanostructured materials. The preparation of polymer nanocomposites using nanosized starch and cellulose is of growing interest in environmental remediation due to the unique characteristics of these nanomaterials, which possess the potential to overcome challenges of toxicity, biodegradability, renewability, accessibility, cost, and energy consumption [42,143-147]. Starch is a mixture of two polymers, the linear amylose and the branched amylopectin. Nanoparticle deriving from native starch can be obtained through chemical, physical, and enzymatic routes [148]. For instance, the enzymatic degradation of starch operated by bacteria leads to the formation of cyclodextrins composed of a hydrophobic cavity and an external hydrophilic surface. Owing to their three-dimensional ring structure, cyclodextrins can encapsulate other molecules making them useful to be applied in the adsorption of toxic pollutants $[149,150]$.

Among the several types and sizes of starch derivatives, nanostructured sponges have been proposed to be among the most promising adsorbents showing good potential for the removal of heavy metals from seawater [84]. Two starch derivatives, the $\beta$-cyclodextrin $(\beta-C D)$ and ${ }^{\circledR}$ linecaps $\left({ }^{\circledR} \mathrm{LC}\right)$, have been employed as polymer backbone to synthesize different starch-based nanosponges (NSs). NSs were able to capture metals at different test concentrations, both in ultrapure water and seawater, showing a different adsorption ability, which was higher for the citrate NSs compared to the pyromellitic NSs. Additionally, NSs can be easily recovered from treated water by filtration. This first study on the efficiency of starch-based NMs in seawater provides the basis for future researches on the assessment of their toxicity on marine organisms [84].

Besides starch, cellulose is one of the most abundant biopolymer sources on the Earth. It is a high molecular weight crystalline homopolymer composed of a linear chain of $\beta$ 
$(1 \rightarrow 4)$ linked anhydrous D-glucose units, which can be extracted from a wide variety of sources, including marine animals, plants, bacteria and algae [151]. It can be also obtained from biomass derived from agricultural or food waste, lowering the impact on the use of this raw material, according to the rules of the circular economy. The cleaving of the hierarchical structure of cellulose, where single chains have meshed into fibers, leads to single cellulose nanofibers [152], characterized by at least one dimension under $100 \mathrm{~nm}$ [153].

Nanocellulose can be obtained via mechanical processing, hydrolysis (enzymatic or acid), and oxidation mediated by 2,2,6,6 tetramethylpiperidinyloxyl (TEMPO) [154,155]. In 2015, a new class of ENMs, the Cellulose-Based Nanosponges (CNS), was developed by using a two-step protocol (Figure 4).
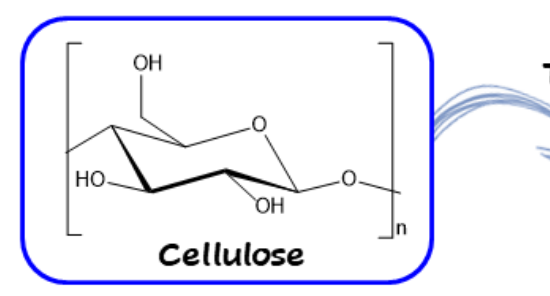

TEMPO-OXidation
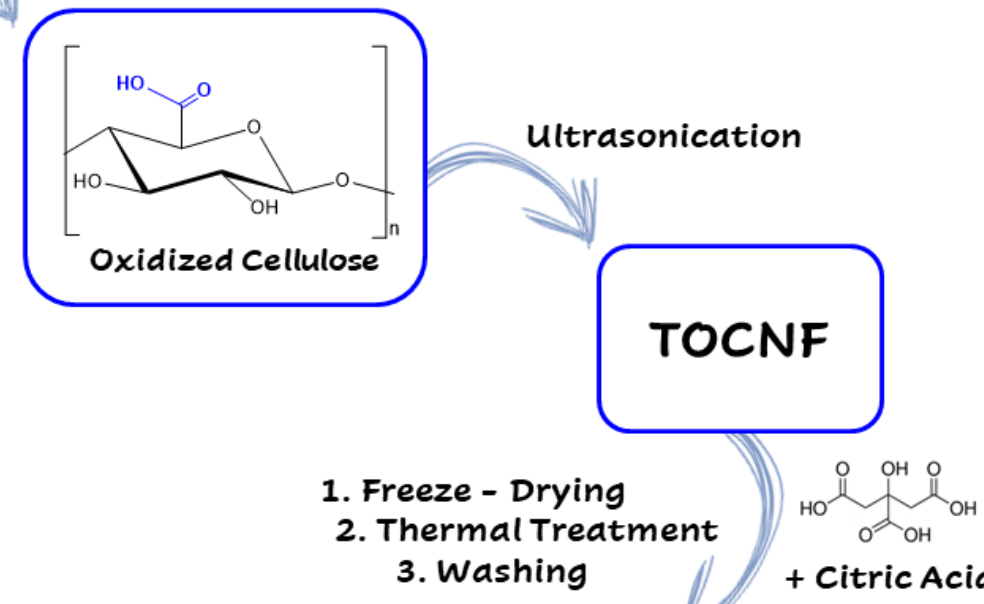

3. Washing
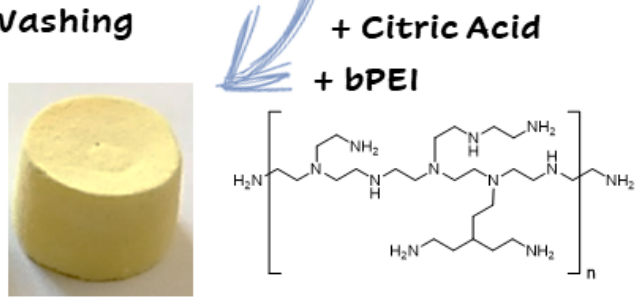

CNS

Figure 4. Synthetic steps in the synthesis of CNS (see text for description).

The first step foresees the production of cellulose nanofibers (CNF) by following the TEMPO-mediated oxidation protocol [156]. Subsequently, the alcoholic groups in the C6 position of glupyranosic rings are partially converted to the corresponding carboxylic groups. Ultrasonication or homogenization at basic $\mathrm{pH}$ favors the defibrillation of cellulose fibers to provide the TEMPO-oxidized CNF (TOCNF), taking advantage from the electrostatic repulsion among deprotonated (and negatively charged) carboxylic moieties. The second step consists of the addition of branched polyethyleneimine (bPEI) and citric acid (CA) to a $2 \% w / w$ water suspension of TOCNF. The resulting highly viscous hydrogel is transferred into well-plates, used as molds, and undergoes thermal treatment consisting of: (i) freezing, (ii) lyophilization, and (iii) heating in oven at about $100{ }^{\circ} \mathrm{C}$. This procedure aims to promote the cross-linking of nanofibers by the formation of amidic bonds between the carboxylic groups present TOCNF backbone and the amine moieties of the bPEI polymer. The resulting CNS evidences a nanoporous structure characterized by a high chemical and mechanical stability [86]. CNS, used as it is or ground into powder, have demonstrated high efficiency to remove heavy metals $(\mathrm{Zn}, \mathrm{Cd}, \mathrm{Cr}, \mathrm{Hg}, \mathrm{Ni}, \mathrm{Cu})$ and organic dyes from 
water and artificial seawater $[45,85,89,157,158]$. More importantly, these nanostructured materials have been synthesized and optimized following the lab scale, the eco-design concept previously discussed, in order to ensure the eco-safety of the nanosponge, while preserving its remediation efficiency (Figure 5).

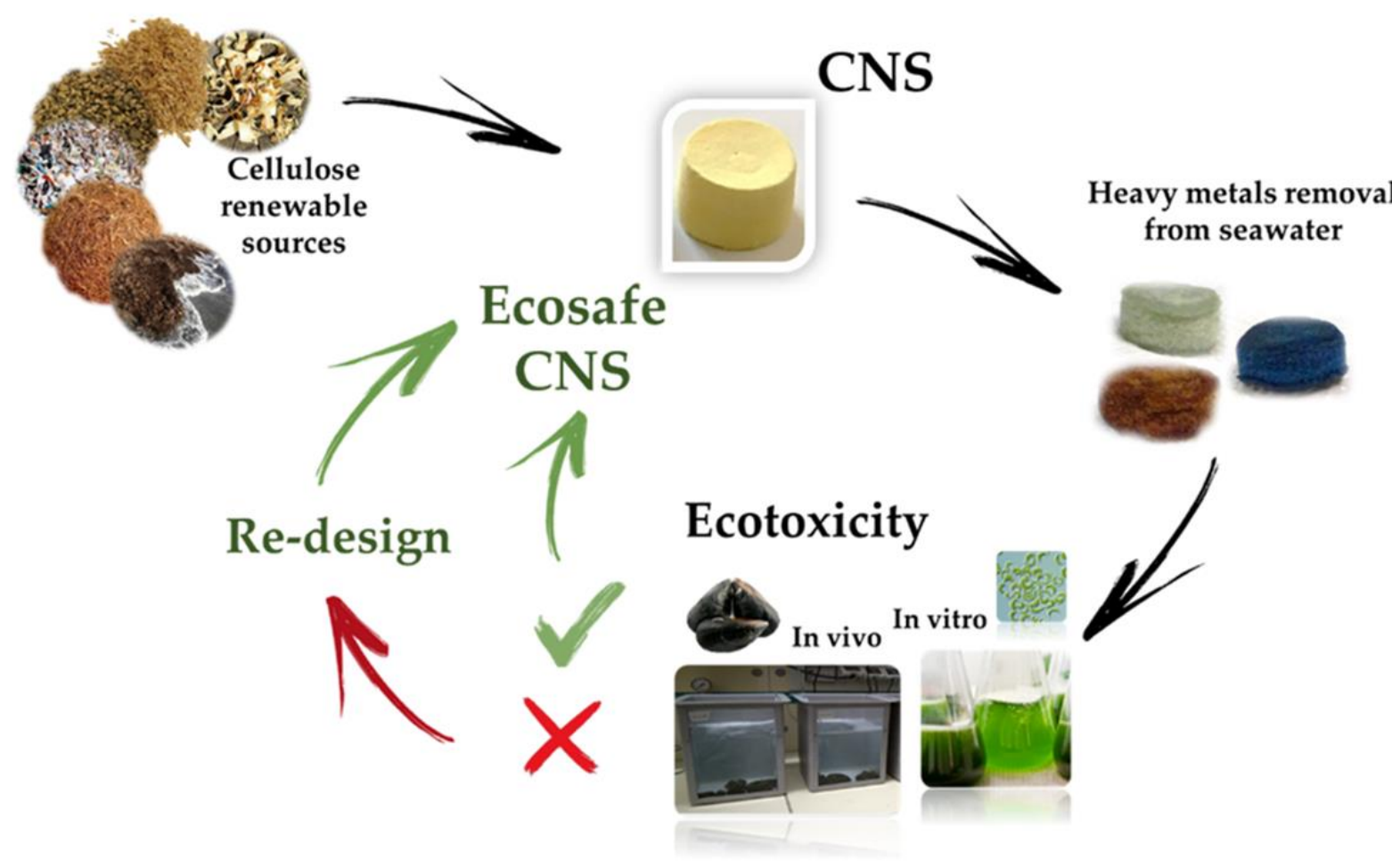

Figure 5. Eco-design of nanostructured cellulose sponges (CNS) for the remediation of heavy metal polluted seawater (modified by [45]).

The ecotoxicological evaluation of CNS class has been performed using species representing two levels of the marine trophic chain: the alga Dunaliella tertiolecta and the mussel M. galloprovincialis, representing the primary producer and the primary consumer, respectively, in the trophic chain. CNS did not affect the growth rate of the marine alga, supporting the ecosafety of these ENMs and promoting its application in nanoremediation [45]. However, the bPEI, a component of CNS, was able to reduce the algal growth. Hence, different formulations of CNS have been re-designed by changing the amount of two key components of CNS, bPEI and citric acid. Among the new formulations, the CNS with the following components mass ratio: $\mathrm{bPEI} / \mathrm{TOCNF} / \mathrm{CA}$ 1:1:18\% ensured both the remediation efficiency in ASW and the ecosafety in algae and mussels [45]. In a different study, the cellular and tissue responses in mussels were measured after $48 \mathrm{~h}$ exposure in four different experimental conditions: ASW, Zn contaminated ASW, CNS, and ASW after CNS treatment [89]. The cellular bioassays showed that the lysosomal membrane stability, the frequency of nuclear abnormalities, the DNA integrity and apoptotic cells in gill, the frequency of micronucleus in hemocytes were not affected in mussels exposed to CNS. Moreover, the genotoxic, cytotoxic, and histological damages induced by $\mathrm{Zn}$ were fully recovered following CNS treatment. Altogether, these results support the CNS ability to remove Zn from ASW and their ecosafety [89].

Carbohydrates are commonly used also for gel preparations. Recently, a nanostructuredcellulose hydrogel was able to remove efficiently radioactive Cs from seawater maintaining its adsorption stability for a long time [87]. The super adsorption efficiency of nanocellulose hydrogels in the removal of dyes or oil-spilled from water and the potentiality of polysaccharides-based nanocomposites for environmental remediation have been demon- 
strated [159-162]. However, additional efforts are required to implement the knowledge on their performances and ecotoxicological impact.

\subsection{Composite-Based Nanomaterials}

Ongoing innovation for an ecosafe nanotechnology generated new solutions deriving from the integration of carbon-based, metal-based, or polysaccharides-based NMs. Consequently, the border which separates the classes is labile. Therefore, the classification of NMs described above should not be considered conclusive. Combining the benefits of magnetic PB and GO, Yang and coworkers [88] designed an exceptional nanocomposite material for the removal of radioactive $\mathrm{Cs}$ from water, the $\mathrm{PB} / \mathrm{Fe}_{3} \mathrm{O}_{4} / \mathrm{GO}$ nanocomposites, characterized by a low aggregation rate, a high adsorption surface area and high stability. Furthermore, considering the main components of these innovative ENMs, the $\mathrm{PB} / \mathrm{Fe}_{3} \mathrm{O}_{4} / \mathrm{GO}$ nanocomposites possess all the characteristics to be a cheap, reusable, and eco-friendly material for Cs-decontamination in the marine environment, but the ecotoxicological assessment remains to be explored.

\section{Conclusions}

Nanotechnology has grown exponentially in the last decades, resulting in the production of huge amount of ENMs for multiple applications. The improved ability to manipulate matter has driven the progressive interconnection of nanotechnology with environmental remediation, until the recent application of ENMs for marine environmental remediation. ENMs applications provide new possibilities to face environmental challenges since they have demonstrated high effectivity in the degradation and/or removal of contaminants. Nanoremediation techniques are more effective in time and costs, respect to conventional remediation methods [10], but the main challenge is to develop ENMs able to remove contaminants from environmental matrices (soil, air, and water) utilizing natural and renewable sources, to safeguard environment and consequently human health. Nanotechnology offers safe and green approaches, which can revolutionize the environmental remediation techniques by preventing the formation of secondary by-products and decomposing some of toxic pollutants with zero waste. However, there are several uncertainties regarding the fundamental features of this technology, which have made it difficult to engineer applications for optimal performance or to assess the risk to human or ecological health. In the future, since it is expected that several nanotools will be developed and applied for environmental remediation, it will be mandatory to closely monitor their ecosafety.

The environmental hazard assessment of each new synthetized ENM, as well as the supervision of the whole life cycle of ENMs for marine nanoremediation, shows some weaknesses, which lead to the following considerations. The use of ENMs for salt-water clean-up made little and slow progress compared to their application in other fields, or in water treatments. Most of the studies on ENMs for marine environmental remediation does not progress until the pilot-scale or over, but it is stacked at the lab-scale. One reason that gets slower the practical application of nanoremediation in the marine environment is the absence of a shared project with manufacturing industries. Hence, bettercoordinated communication between research entities, governments, and industries should be implemented with the objective to boost clean energy and sustainable technologies.

In relation to the ecotoxicological evaluation of ENMs for marine nanoremediation purposes, in situ investigation of ENMs, long-term and chronic studies should be incremented over short-term and acute ecotoxicity tests. To our knowledge, studies in marine matrix lack data on some trophic levels being mainly focused on primary producers and consumers, such as algae and mussels. Additionally, the majority of ecotoxicological investigations are concentrated on biomarkers in adults, while little attention has been given to reproductive efficiency, which determines the survival or extinction of a given population. Compared to non-aquatic organisms, the external fertilization that is present in some key marine species directly exposes the gametes and the early developmental stages 
to contaminants. Hence, from an ecological perspective, we would like to propose the reproduction as a biomarker of exposure and effect to ENMs in marine environment [163]. On the other hand, ecotoxicogenomic approach reflects the latest efforts to find sensitive biomarkers to ENM exposure, contributing to gain a complete understanding of the action of ENMs to marine organisms.

The last advances in the biomarkers and tools, together with the new knowledge in the environmental behavior of ENMs, could integrate future nanoecotoxicology studies for an efficient ecological risk assessment, able to describe more realistically the ENM exposure scenarios and to predict ecosystem impact caused by ENM application.

Finally, we would like to point out the need for a standardized approach to nanosafety that integrates the chemical, physical and biological aspects. To date, the eco-design strategy seems to face this challenge for green and safe nanomaterials.

Funding: This research was supported by the project NANOBOND (Nanomaterials for Remediation of Environmental Matrices associated to Dewatering), funded by Regione Toscana, Italy (POR CReO FESR Toscana 2014e2020-30/07/2014-LA 1.1.5 CUP 3389.30072014.067000007).

Institutional Review Board Statement: Not applicable.

Informed Consent Statement: Not applicable.

Data Availability Statement: Not applicable.

Acknowledgments: Esposito MC has been supported by a PhD fellowship funded by the Stazione Zoologica Anton Dohrn (Open University—Stazione Zoologica Anton Dohrn PhD Program).

Conflicts of Interest: The authors declare no conflict of interest.

$\begin{array}{ll}\text { Abbreviations } & \\ { }^{\circledR} \text { LC } & { }^{\circledR} \text { Linecaps } \\ \text { 3D } & \text { Three-Dimensional } \\ \text { AgNPs } & \text { Silver Nanoparticles } \\ \text { ASW } & \text { Artificial Sea Water } \\ \text { bPEI } & \text { Branched Polyethyleneimine } \\ \text { CA } & \text { Citric Acid } \\ \text { CMs } & \text { Carbon Microspheres } \\ \text { CNF } & \text { Cellulose Nanofiber } \\ \text { CNS } & \text { Cellulose-Based Nanosponge } \\ \text { CNTs } & \text { Carbon Nanotubes } \\ \text { CTAB } & \text { Cetyl Trimethyl Ammonium Bromide } \\ \text { CTS-g-CNTs } & \text { Chitosan-Grafted Carbon Nanotubes } \\ \text { CuHCF } & \text { Copper Hexacyanoferrate } \\ \text { DOM } & \text { Dissolved Organic Matter } \\ \text { ENMs } & \text { Engineered Nanomaterials } \\ \text { ERA } & \text { Ecological Risk Assessment } \\ \text { GO } & \text { Graphene Oxide } \\ \text { GO-CH-based } & \text { Graphene Oxide Chitosan-Based } \\ \text { GO-PEI } & \text { Graphene Oxide Functionalized with Polyethyleneimine } \\ \text { GSR } & \text { Green And Sustainable Remediation } \\ \text { HCF } & \text { Hexacyanoferrate } \\ \text { HNTs } & \text { Halloysite Nanotubes } \\ \text { KBr } & \text { Potassium Bromide } \\ \text { KTiFC } & \text { Potassium Titanium Ferrocyanide } \\ \text { LCA } & \text { Life-Cycle Assessment } \\ \text { M-EG } & \text { Modified Extended Graphene } \\ \text { MnFe }{ }_{2} \mathrm{O}_{4}-N P s & \text { Manganese-Ferrite Nanoparticles } \\ & \\ & \end{array}$




$\begin{array}{ll}\text { NF } & \text { Nanofiltration } \\ \text { NMs } & \text { Nanomaterials } \\ \text { NOM } & \text { Natural Organic Matter } \\ \text { NPs } & \text { Nanoparticles } \\ \text { NSs } & \text { Nanosponges } \\ \mathrm{nTiO}_{2} & \text { Titanium Dioxide Nanoparticles } \\ \text { nZVI } & \text { Nanoscale Zero-Valent Iron } \\ \text { PAH } & \text { Polycyclic Aromatic Hydrocarbons } \\ \text { PB } & \text { Prussian Blue } \\ \text { PBMHBs } & \text { Prussian Blue-Embedded Magnetic Hydrogel Beads } \\ \text { POPs } & \text { Persistent Organic Pollutants } \\ \text { REACH } & \text { Registration, Evaluation, Authorization and Restriction of Chemic } \\ \text { TEMPO } & \text { 2,2,6,6 Tetramethylpiperidinyloxyl } \\ \text { TFC } & \text { Thin-Film Composites } \\ \text { TOCNF } & \text { TEMPO-Oxidized CNF } \\ \text { TPT } & \text { Triphenyltin Chloride } \\ \text { ZIF-8-FC } & \text { Zeolitic Imidazolate Framework (ZIF-8) Functionalized by Ferrocyanide (FC) } \\ \beta-C D & \text { B-Cyclodextrin }\end{array}$

\section{References}

1. Tornero, V.; Hanke, G. Chemical contaminants entering the marine environment from sea-based sources: A review with a focus on European seas. Mar. Poll. Bull. 2016, 112, 17-38. [CrossRef] [PubMed]

2. Blaise, C.; Gagné, F.; Ferard, J.; Eullaffroy, P. Ecotoxicity of selected nano-materials to aquatic organisms. Environ. Toxicol. 2008, 23, 591-598. [CrossRef] [PubMed]

3. Biswas, A.; Bayer, I.S.; Biris, A.S.; Wang, T.; Dervishi, E.; Faupel, F. Advances in top-down and bottom-up surface nanofabrication: Techniques, applications \& future prospects. Adv. Colloid Interface Sci. 2012, 170, 2-27. [PubMed]

4. Hobbs, R.G.; Petkov, N.; Holmes, J.D. Semiconductor nanowire fabrication by bottom-up and top-down paradigms. Chem. Mater. 2012, 24, 1975-1991. [CrossRef]

5. Bardos, P.; Merly, C.; Kvapil, P.; Koschitzky, H.P. Status of nanoremediation and its potential for future deployment: Risk-benefit and benchmarking appraisals. Remed. J. 2018, 28, 43-56. [CrossRef]

6. Lee, C.-C.; Lien, H.-L.; Wu, S.-C.; Doong, R.-A.; Chao, C.-C. Reduction of priority pollutants by nanoscale zerovalent iron in subsurface environments. In Aquananotechnology: Global Prospects; Reisner, D.E., Pradeep, T., Eds.; CRC Press, Taylor and Francis Group: Boca Raton, FL, USA, 2014; Volume 63.

7. Guerra, F.D.; Attia, M.F.; Whitehead, D.C.; Alexis, F. Nanotechnology for environmental remediation: Materials and applications. Molecules 2018, 23, 1760. [CrossRef]

8. U.S. EPA. National Priorities List (NPL) Sites-By State. 2009. Available online: https://www.epa.gov/superfund/nationalpriorities-list-npl-sites-state (accessed on 11 January 2021).

9. Mueller, N.C.; Nowack, B. Nanoparticles for remediation: Solving big problems with little particles. Elements 2010, 6, 395-400. [CrossRef]

10. The Project on Emerging Nanotechnologies (PEN). Nanoremediation Map. 2015. Available online: http:/ / www.nanotechproject. org/inventories/remediation_map/ (accessed on 15 January 2021).

11. Masciangioli, T.; Zhang, W.-X. Peer reviewed: Environmental technologies at the nanoscale. Environ. Sci. Technol. 2003, 37, 102-108. [CrossRef]

12. Bardos, P.; Bone, B.; Elliott, D.; Hartog, N.; Henstock, J.; Nathanail, P. A Risk/Benefit Approach to the Application of Iron Nanoparticles for the Remediation of Contaminated Sites in the Environment; Department for Environment, Food \& Rural Affairs: Carlisle, UK, 2011.

13. O'Carroll, D.; Sleep, B.; Krol, M.; Boparai, H.; Kocur, C. Nanoscale zero valent iron and bimetallic particles for contaminated site remediation. Adv. Water Resour. 2013, 51, 104-122. [CrossRef]

14. Chapman, E.E.V.; Moore, C.; Campbell, L.M. Evaluation of a nanoscale zero-valent iron amendment as a potential tool to reduce mobility, toxicity, and bioaccumulation of arsenic and mercury from wetland sediments. Environ. Sci. Pollut. Res. 2020, 27, 18757-18772. [CrossRef]

15. Jing, R.; Fusi, S.; Kjellerup, B.V. Remediation of polychlorinated biphenyls (PCBs) in contaminated soils and sediment: State of knowledge and perspectives. Front. Environ. Sci. 2018, 6, 79-96. [CrossRef]

16. Pak, T.; de Lima Luz, L.F.; Tosco, T.; Costa, G.S.R.; Rosa, P.R.R.; Archilha, N.L. Pore-scale investigation of the use of reactive nanoparticles for in situ remediation of contaminated groundwater source. Proc. Natl. Acad. Sci. USA 2020, 117, 13366-13373. [CrossRef]

17. Pilipović, D.T.; Kerkez, D.; Dalmacija, B.; Slijepčević, N.; Krčmar, D.; Rađenović, D.; Bečelić-Tomin, M. Remediation of toxic metal contaminated sediment using three types of nZVI supported materials. Bull. Environ. Contam. Toxicol. 2018, 101, 725-731. [CrossRef] 
18. Ibrahim, R.K.; Hayyan, M.; AlSaadi, M.A.; Hayyan, A.; Ibrahim, S. Environmental application of nanotechnology: Air, soil, and water. Environ. Sci. Pollut. Res. 2016, 23, 13754-13788.

19. Liang, Q.; Zhao, D. Immobilization of arsenate in a sandy loam soil using starch-stabilized magnetite nanoparticles. J. Hazard. Mater. 2014, 271, 16-23. [CrossRef]

20. Wang, T.; Liu, Y.; Wang, J.; Wang, X.; Liu, B.; Wang, Y. In-situ remediation of hexavalent chromium contaminated groundwater and saturated soil using stabilized iron sulfide nanoparticles. J. Environ. Manag. 2019, 231, 679-686. [CrossRef]

21. Owoseni, O.; Nyankson, E.; Zhang, Y.; Adams, S.J.; He, J.; McPherson, G.L.; Bose, A.; Gupta, R.B.; John, V.T. Release of surfactant cargo from interfacially-active halloysite clay nanotubes for oil spill remediation. Langmuir 2014, 30, 13533-13541. [CrossRef]

22. Shen, Q.; Xu, S.J.; Xu, Z.L.; Zhang, H.Z.; Dong, Z.Q. Novel thin-film nanocomposite membrane with water-soluble polyhydroxylated fullerene for the separation of $\mathrm{Mg}^{2+} / \mathrm{Li}^{+}$aqueous solution. J. Appl. Polym. Sci. 2019, 136, 48029-48043. [CrossRef]

23. Yang, H.-M.; Hwang, J.R.; Lee, D.Y.; Kim, K.B.; Park, C.W.; Kim, H.R.; Lee, K.-W. Eco-friendly one-pot synthesis of Prussian blue-embedded magnetic hydrogel beads for the removal of cesium from water. Sci. Rep. 2018, 8, 1-10. [CrossRef]

24. Corsi, I.; Fiorati, A.; Grassi, G.; Bartolozzi, I.; Daddi, T.; Melone, L.; Punta, C. Environmentally sustainable and ecosafe polysaccharide-based materials for water nano-treatment: An eco-design study. Materials 2018, 11, 1228. [CrossRef]

25. Patil, S.S.; Shedbalkar, U.U.; Truskewycz, A.; Chopade, B.A.; Ball, A.S. Nanoparticles for environmental clean-up: A review of potential risks and emerging solutions. Environ. Technol. Innov. 2016, 5, 10-21. [CrossRef]

26. Klaine, S.J.; Alvarez, P.J.; Batley, G.E.; Fernandes, T.F.; Handy, R.D.; Lyon, D.Y.; Mahendra, S.; McLaughlin, M.J.; Lead, J.R. Nanomaterials in the environment: Behavior, fate, bioavailability, and effects. Environ. Toxicol. Chem. 2008, 27, $1825-1851$. [CrossRef] [PubMed]

27. Martino, L.E.; Dona, C.L.; Dicerbo, J.; Hawkins, A.; Moore, B.; Horner, R. Green and sustainable remediation practices in Federal Agency cleanup programs. Environ. Earth Sci. 2016, 75, 1-13. [CrossRef]

28. Corsi, I.; Cherr, G.N.; Lenihan, H.S.; Labille, J.; Hassellov, M.; Canesi, L.; Dondero, F.; Frenzilli, G.; Hristozov, D.; Puntes, V. Common strategies and technologies for the ecosafety assessment and design of nanomaterials entering the marine environment. ACS Nano 2014, 8, 9694-9709. [CrossRef] [PubMed]

29. Matranga, V.; Corsi, I. Toxic effects of engineered nanoparticles in the marine environment: Model organisms and molecular approaches. Mar. Environ. Res. 2012, 76, 32-40. [CrossRef] [PubMed]

30. Ahlbom, A.; Bridges, J.; De Jong, W.; Jung, T.; Mattsson, O.; Pagès, J.M.; Rydzynski, K.; Stahl, D.; Thomsen, M.; Thomsen, M. Scientific Committee on Emerging and Newly Identified Health Risks SCENIHR Risk Assessment of Products of Nanotechnologies. 2009. Available online: https:/ / ec.europa.eu/health/ph_risk/committees/04_scenihr/docs/scenihr_o_023.pdf (accessed on 19 January 2021).

31. Blasco, J.; Corsi, I.; Matranga, V. Particles in the oceans: Implication for a safe marine environment. Mar. Environ. Res. 2015, 111, 1-4. [CrossRef] [PubMed]

32. Handy, R.D.; Von der Kammer, F.; Lead, J.R.; Hassellöv, M.; Owen, R.; Crane, M. The ecotoxicology and chemistry of manufactured nanoparticles. Ecotoxicology 2008, 17, 287-314. [CrossRef] [PubMed]

33. Scott-Fordsmand, J.J.; Peijnenburg, W.J.; Semenzin, E.; Nowack, B.; Hunt, N.; Hristozov, D.; Marcomini, A.; Irfan, M.A.; Jiménez, A.S.; Landsiedel, R. Environmental risk assessment strategy for nanomaterials. Int. J. Environ. Res. Public Health 2017, $14,1251$. [CrossRef]

34. Rana, S.; Kalaichelvan, P. Ecotoxicity of nanoparticles. ISRN Toxicol. 2013, 2013, 574648-574660. [CrossRef]

35. Gondikas, A.; Gallego-Urrea, J.; Halbach, M.; Derrien, N.; Hassellöv, M. Nanomaterial fate in seawater: A rapid sink or intermittent stabilization? Front. Environ. Sci. 2020, 8, 151-160. [CrossRef]

36. Danielsson, K.; Persson, P.; Gallego-Urrea, J.; Abbas, Z.; Rosenqvist, J.; Jonsson, C. Effects of the adsorption of NOM model molecules on the aggregation of $\mathrm{TiO}_{2}$ nanoparticles in aqueous suspensions. Nanoimpact 2018, 10, 177-187. [CrossRef]

37. Surette, M.C.; Nason, J.A. Effects of surface coating character and interactions with natural organic matter on the colloidal stability of gold nanoparticles. Environ. Sci. Nano 2016, 3, 1144-1152. [CrossRef]

38. He, X.; Fu, P.; Aker, W.G.; Hwang, H.-M. Toxicity of engineered nanomaterials mediated by nano-bio-eco interactions. J. Environ. Sci. Health C 2018, 36, 21-42. [CrossRef] [PubMed]

39. Lundqvist, M.; Stigler, J.; Elia, G.; Lynch, I.; Cedervall, T.; Dawson, K.A. Nanoparticle size and surface properties determine the protein corona with possible implications for biological impacts. Proc. Natl. Acad. Sci. USA 2008, 105, 14265-14270. [CrossRef]

40. Monopoli, M.P.; Walczyk, D.; Campbell, A.; Elia, G.; Lynch, I.; Baldelli Bombelli, F.; Dawson, K.A. Physical-chemical aspects of protein corona: Relevance to in vitro and in vivo biological impacts of nanoparticles. J. Am. Chem. Soc. 2011, 133, 2525-2534. [CrossRef]

41. Nasser, F.; Constantinou, J.; Lynch, I. Nanomaterials in the Environment Acquire an "Eco-Corona" Impacting their Toxicity to Daphnia Magna-A Call for Updating Toxicity Testing Policies. Proteomics 2020, 20, e1800412. [CrossRef]

42. Corsi, I.; Fiorati, A.; Grassi, G.; Pedrazzo, A.R.; Caldera, F.; Trotta, F.; Punta, C. Ecosafe nanomaterials for environmental remediation. In Nanomaterials for the Detection and Removal of Wastewater Pollutants; Elsevier: Amsterdam, The Nederland, 2020; pp. 383-405.

43. Upreti, G.; Dhingra, R.; Naidu, S.; Atuahene, I.; Sawhney, R. Life cycle assessment of nanomaterials. In Green Processes for Nanotechnology; Springer: Berlin/Heidelberg, Germany, 2015; pp. 393-408. 
44. U.S. EPA. Incorporating Sustainable Practices into Site Remediation; EPA 542-R-08-002; U.S. Environmental Protection Agency: Washington, DC, USA, 2008.

45. Fiorati, A.; Grassi, G.; Graziano, A.; Liberatori, G.; Pastori, N.; Melone, L.; Bonciani, L.; Pontorno, L.; Punta, C.; Corsi, I. Eco-design of nanostructured cellulose sponges for sea-water decontamination from heavy metal ions. J. Clean. Prod. 2020, 246, 119009-119020. [CrossRef]

46. Oberdörster, G.; Maynard, A.; Donaldson, K.; Castranova, V.; Fitzpatrick, J.; Ausman, K.; Carter, J.; Karn, B.; Kreyling, W.; Lai, D. Principles for characterizing the potential human health effects from exposure to nanomaterials: Elements of a screening strategy. Part. Fibre Toxicol. 2005, 2, 1-35. [CrossRef]

47. Corsi, I.; Bergami, E.; Grassi, G. Behavior and bio-interactions of anthropogenic particles in marine environment for a more realistic ecological risk assessment. Front. Environ. Sci. 2020, 8, 60-81. [CrossRef]

48. Kahru, A.; Dubourguier, H.-C. From ecotoxicology to nanoecotoxicology. Toxicology 2010, 269, 105-119. [CrossRef]

49. Selck, H.; Handy, R.D.; Fernandes, T.F.; Klaine, S.J.; Petersen, E.J. Nanomaterials in the aquatic environment: A European Union-United States perspective on the status of ecotoxicity testing, research priorities, and challenges ahead. Environ. Toxicol. Chem. 2016, 35, 1055-1067. [CrossRef] [PubMed]

50. Depledge, M.; Fossi, M. The role of biomarkers in environmental assessment (2). Invertebrates. Ecotoxicology 1994, 3, 161-172. [CrossRef] [PubMed]

51. Nowack, B.; Baalousha, M.; Bornhöft, N.; Chaudhry, Q.; Cornelis, G.; Cotterill, J.; Gondikas, A.; Hassellöv, M.; Lead, J.; Mitrano, D.M. Progress towards the validation of modeled environmental concentrations of engineered nanomaterials by analytical measurements. Environ. Sci. Nano 2015, 2, 421-428. [CrossRef]

52. Blaise, C. Microbiotesting: An expanding field in aquatic toxicology. Ecotoxicol. Environ. Saf. 1998, 40, 115-119. [CrossRef]

53. Stern, S.T.; Adiseshaiah, P.P.; Crist, R.M. Autophagy and lysosomal dysfunction as emerging mechanisms of nanomaterial toxicity. Part. Fibre Toxicol. 2012, 9, 1-17. [CrossRef] [PubMed]

54. Châtel, A.; Mouneyrac, C. Signaling pathways involved in metal-based nanomaterial toxicity towards aquatic organisms. Comp Biochem. Physiol. C Toxicol. Pharmacol. 2017, 196, 61-70. [CrossRef] [PubMed]

55. Chen, C.W.; Binh, N.T.; Chang, Y.K.; Hung, C.M.; Dong, C.D. Remediation of marine sediments contaminated with PAHs using sodium persulfate activated by temperature and nanoscale zero valent iron. Adv. Mater. Res. 2014, 1044-1045, 380-383. [CrossRef]

56. Snape, J.R.; Maund, S.J.; Pickford, D.B.; Hutchinson, T.H. Ecotoxicogenomics: The challenge of integrating genomics into aquatic and terrestrial ecotoxicology. Aquat. Toxicol. 2004, 67, 143-154. [CrossRef]

57. Revel, M.; Châtel, A.; Mouneyrac, C. Omics tools: New challenges in aquatic nanotoxicology? Aquat. Toxicol. 2017, 193, 72-85. [CrossRef]

58. Beliaeff, B.; Burgeot, T. Integrated biomarker response: A useful tool for ecological risk assessment. Environ. Toxicol. Chem. 2002, 21, 1316-1322. [CrossRef]

59. Breitholtz, M.; Rudén, C.; Hansson, S.O.; Bengtsson, B.-E. Ten challenges for improved ecotoxicological testing in environmental risk assessment. Ecotoxicol. Environ. Saf. 2006, 63, 324-335. [CrossRef]

60. Kim, W.-K.; Lee, S.-K.; Jung, J. Integrated assessment of biomarker responses in common carp (Cyprinus carpio) exposed to perfluorinated organic compounds. J. Hazard. Mater. 2010, 180, 395-400. [CrossRef]

61. Xia, B.; Zhu, L.; Han, Q.; Sun, X.; Chen, B.; Qu, K. Effects of TiO2 nanoparticles at predicted environmental relevant concentration on the marine scallop Chlamys farreri: An integrated biomarker approach. Environ. Toxicol. Pharmacol. 2017, 50, 128-135. [CrossRef]

62. Somorjai, G.A.; McCrea, K. Roadmap for catalysis science in the 21st century: A personal view of building the future on past and present accomplishments. Appl. Catal. A 2001, 222, 3-18. [CrossRef]

63. Adeleye, A.S.; Conway, J.R.; Garner, K.; Huang, Y.; Su, Y.; Keller, A.A. Engineered nanomaterials for water treatment and remediation: Costs, benefits, and applicability. Chem. Eng. J. 2016, 286, 640-662. [CrossRef]

64. Singh, K.P.; Singh, A.K.; Gupta, S.; Rai, P. Modeling and optimization of reductive degradation of chloramphenicol in aqueous solution by zero-valent bimetallic nanoparticles. Environ. Sci. Poll. Res. 2012, 19, 2063-2078. [CrossRef]

65. Zhou, L.; Ji, L.; Ma, P.-C.; Shao, Y.; Zhang, H.; Gao, W.; Li, Y. Development of carbon nanotubes $/$ CoFe $\mathrm{O}_{4}$ magnetic hybrid material for removal of tetrabromobisphenol A and $\mathrm{Pb}$ (II). J. Hazard. Mater. 2014, 265, 104-114. [CrossRef]

66. Diallo, M.S.; Kotte, M.R.; Cho, M. Mining critical metals and elements from seawater: Opportunities and challenges. Environ. Sci. Technol. 2015, 49, 9390-9399. [CrossRef]

67. Su, C.; Puls, R.W.; Krug, T.A.; Watling, M.T.; O'Hara, S.K.; Quinn, J.W.; Ruiz, N.E. A two and half-year-performance evaluation of a field test on treatment of source zone tetrachloroethene and its chlorinated daughter products using emulsified zero valent iron nanoparticles. Water Res. 2012, 46, 5071-5084. [CrossRef]

68. Jiang, Z.-R.; Ge, J.; Zhou, Y.-X.; Wang, Z.U.; Chen, D.; Yu, S.-H.; Jiang, H.-L. Coating sponge with a hydrophobic porous coordination polymer containing a low-energy CF 3-decorated surface for continuous pumping recovery of an oil spill from water. NPG Asia Mater. 2016, 8, e253. [CrossRef]

69. Yang, S.; Shao, D.; Wang, X.; Hou, G.; Nagatsu, M.; Tan, X.; Ren, X.; Yu, J. Design of chitosan-grafted carbon nanotubes: Evaluation of how the-OH functional group affects $\mathrm{Cs}^{+}$adsorption. Mar. Drugs 2015, 13, 3116-3131. [CrossRef]

70. Coppola, F.; Bessa, A.; Henriques, B.; Russo, T.; Soares, A.M.; Figueira, E.; Marques, P.A.; Polese, G.; Di Cosmo, A.; Pereira, E. Oxidative stress, metabolic and histopathological alterations in mussels exposed to remediated seawater by GO-PEI after contamination with mercury. Comp. Biochem. Physiol. Part A Mol. Integr. Physiol. 2020, 243, 110674-110689. [CrossRef] 
71. Coppola, F.; Bessa, A.; Henriques, B.; Russo, T.; Soares, A.M.; Figueira, E.; Pereira, E.; Marques, P.; Polese, G.; Freitas, R. The Role of Temperature on the Impact of Remediated Water towards Marine Organisms. Water 2020, 12, 2148. [CrossRef]

72. Coppola, F.; Tavares, D.S.; Henriques, B.; Monteiro, R.; Trindade, T.; Figueira, E.; Soares, A.M.; Pereira, E.; Freitas, R. Can water remediated by manganese spinel ferrite nanoparticles be safe for marine bivalves? Sci. Total Environ. 2020, 723, 137798-137812. [CrossRef] [PubMed]

73. Coppola, F.; Tavares, D.S.; Henriques, B.; Monteiro, R.; Trindade, T.; Soares, A.M.; Figueira, E.; Polese, G.; Pereira, E.; Freitas, R. Remediation of arsenic from contaminated seawater using manganese spinel ferrite nanoparticles: Ecotoxicological evaluation in Mytilus galloprovincialis. Environ. Res. 2019, 175, 200-212. [CrossRef] [PubMed]

74. Sun, Y.; Lei, C.; Khan, E.; Chen, S.S.; Tsang, D.C.; Ok, Y.S.; Lin, D.; Feng, Y.; Li, X.-d. Aging effects on chemical transformation and metal (loid) removal by entrapped nanoscale zero-valent iron for hydraulic fracturing wastewater treatment. Sci. Total Environ. 2018, 615, 498-507. [CrossRef]

75. Fatoki, O.S.; Ayanda, O.S.; Adekola, F.A.; Ximba, B.J. Sorption of Triphenyltin Chloride to n Fe3O4, Fly Ash, and n Fe3O4/Fly Ash Composite Material in Seawater. Clean-Soil Air Water 2014, 42, 472-479. [CrossRef]

76. Torad, N.L.; Takahashi, A.; Kawakami, M.; Kawamoto, T.; Tanaka, H. Decontamination of very dilute Cs in seawater by a coagulation-precipitation method using a nanoparticle slurry of copper hexacyanoferrate. Environ. Sci. Water Res. Technol. 2019, 5 , 1328-1338. [CrossRef]

77. Le, Q.T.N.; Cho, K. Caesium adsorption on a zeolitic imidazolate framework (ZIF-8) functionalized by ferrocyanide. J. Colloid Interface Sci. 2021, 581, 741-750. [CrossRef]

78. Yi, R.; Ye, G.; Wu, F.; Wen, M.; Feng, X.; Chen, J. Highly efficient removal of 137 Cs in seawater by potassium titanium ferrocyanide functionalized magnetic microspheres with multilayer core-shell structure. RSC Adv. 2014, 4, 37600-37608. [CrossRef]

79. Dong, C.-D.; Lu, Y.-C.; Chang, J.-H.; Wang, T.-H.; Chen, C.-W.; Hung, C.-M. Enhanced persulfate degradation of PAHcontaminated sediments using magnetic carbon microspheres as the catalyst substrate. Process Saf. Environ. Prot. 2019, 125, 219-227. [CrossRef]

80. Zhang, Z.; Li, M.; Chen, W.; Zhu, S.; Liu, N.; Zhu, L. Immobilization of lead and cadmium from aqueous solution and contaminated sediment using nano-hydroxyapatite. Environ. Pollut. 2010, 158, 514-519. [CrossRef]

81. De Gisi, S.; Minetto, D.; Lofrano, G.; Libralato, G.; Conte, B.; Todaro, F.; Notarnicola, M. Nano-scale zero valent iron (nZVI) treatment of marine sediments slightly polluted by heavy metals. Chem. Eng. Trans 2017, 60, 139-144.

82. Hong, J.; Xie, J.; Mirshahghassemi, S.; Lead, J. Metal (Cd, Cr, Ni, Pb) removal from environmentally relevant waters using polyvinylpyrrolidone-coated magnetite nanoparticles. RSC Adv. 2020, 10, 3266-3276. [CrossRef]

83. Alabresm, A.; Chen, Y.P.; Decho, A.W.; Lead, J. A novel method for the synergistic remediation of oil-water mixtures using nanoparticles and oil-degrading bacteria. Sci. Total Environ. 2018, 630, 1292-1297. [CrossRef] [PubMed]

84. Rubin Pedrazzo, A.; Smarra, A.; Caldera, F.; Musso, G.; Dhakar, N.K.; Cecone, C.; Hamedi, A.; Corsi, I.; Trotta, F. Eco-friendly $\beta$-cyclodextrin and linecaps polymers for the removal of heavy metals. Polymers 2019, 11, 1658. [CrossRef] [PubMed]

85. Melone, L.; Rossi, B.; Pastori, N.; Panzeri, W.; Mele, A.; Punta, C. TEMPO-oxidized cellulose cross-linked with branched polyethyleneimine: Nanostructured adsorbent sponges for water remediation. ChemPlusChem 2015, 80, 1408-1415. [CrossRef] [PubMed]

86. Paladini, G.; Venuti, V.; Almásy, L.; Melone, L.; Crupi, V.; Majolino, D.; Pastori, N.; Fiorati, A.; Punta, C. Cross-linked cellulose nano-sponges: A small angle neutron scattering (SANS) study. Cellulose 2019, 26, 9005-9019. [CrossRef]

87. Kim, Y.; Kim, Y.K.; Kim, S.; Harbottle, D.; Lee, J.W. Nanostructured potassium copper hexacyanoferrate-cellulose hydrogel for selective and rapid cesium adsorption. Chem. Eng. J. 2017, 313, 1042-1050. [CrossRef]

88. Yang, H.; Sun, L.; Zhai, J.; Li, H.; Zhao, Y.; Yu, H. In situ controllable synthesis of magnetic Prussian blue/graphene oxide nanocomposites for removal of radioactive cesium in water. J. Mater. Chem. 2014, 2, 326-332. [CrossRef]

89. Liberatori, G.; Grassi, G.; Guidi, P.; Bernardeschi, M.; Fiorati, A.; Scarcelli, V.; Genovese, M.; Faleri, C.; Protano, G.; Frenzilli, G. Effect-based approach to assess nanostructured cellulose sponge removal efficacy of zinc ions from seawater to prevent ecological risks. Nanomaterials 2020, 10, 1283. [CrossRef]

90. Keller, A.A.; Garner, K.; Miller, R.J.; Lenihan, H.S. Toxicity of nano-zero valent iron to freshwater and marine organisms. PLoS ONE 2012, 7, e43983. [CrossRef] [PubMed]

91. Kadar, E.; Dyson, O.; Handy, R.D.; Al-Subiai, S.N. Are reproduction impairments of free spawning marine invertebrates exposed to zero-valent nano-iron associated with dissolution of nanoparticles? Nanotoxicology 2013, 7, 135-143. [CrossRef]

92. Kadar, E.; Simmance, F.; Martin, O.; Voulvoulis, N.; Widdicombe, S.; Mitov, S.; Lead, J.; Readman, J. The influence of engineered $\mathrm{Fe}_{2} \mathrm{O}_{3}$ nanoparticles and soluble $\left(\mathrm{FeCl}_{3}\right)$ iron on the developmental toxicity caused by $\mathrm{CO}_{2}$-induced seawater acidification. Environ. Pollut. 2010, 158, 3490-3497. [CrossRef]

93. Alabresm, A.; Mirshahghassemi, S.; Chandler, G.T.; Decho, A.W.; Lead, J. Use of PVP-coated magnetite nanoparticles to ameliorate oil toxicity to an estuarine meiobenthic copepod and stimulate the growth of oil-degrading bacteria. Environ. Sci. Nano 2017, 4, 1859-1865. [CrossRef]

94. Santhosh, C.; Velmurugan, V.; Jacob, G.; Jeong, S.K.; Grace, A.N.; Bhatnagar, A. Role of nanomaterials in water treatment applications: A review. Chem. Eng. J. 2016, 306, 1116-1137. [CrossRef]

95. Tavares, D.S.; Daniel-da-Silva, A.L.; Lopes, C.B.; Silva, N.J.; Amaral, V.S.; Rocha, J.; Pereira, E.; Trindade, T. Efficient sorbents based on magnetite coated with siliceous hybrid shells for removal of mercury ions. J. Mater. Chem. 2013, 1, 8134-8143. [CrossRef] 
96. Martinez-Vargas, S.; Martínez, A.I.; Hernández-Beteta, E.E.; Mijangos-Ricardez, O.F.; Vázquez-Hipólito, V.; Patiño-Carachure, C.; López-Luna, J. As (III) and As (V) adsorption on manganese ferrite nanoparticles. J. Mol. Struct. 2018, 1154, 524-534. [CrossRef]

97. Khin, M.M.; Nair, A.S.; Babu, V.J.; Murugan, R.; Ramakrishna, S. A review on nanomaterials for environmental remediation. Energy Environ. Sci. 2012, 5, 8075-8109. [CrossRef]

98. Jang, M.-H.; Lim, M.; Hwang, Y.S. Potential environmental implications of nanoscale zero-valent iron particles for environmental remediation. Environ. Health Toxicol. 2014, 29, e2014022. [CrossRef]

99. Mueller, N.C.; Braun, J.; Bruns, J.; Černík, M.; Rissing, P.; Rickerby, D.; Nowack, B. Application of nanoscale zero valent iron (NZVI) for groundwater remediation in Europe. Environ. Sci. Pollut. Res. 2012, 19, 550-558. [CrossRef]

100. Němeček, J.; Lhotský, O.; Cajthaml, T. Nanoscale zero-valent iron application for in situ reduction of hexavalent chromium and its effects on indigenous microorganism populations. Sci. Total Environ. 2014, 485, 739-747. [CrossRef]

101. Tang, S.C.; Lo, I.M. Magnetic nanoparticles: Essential factors for sustainable environmental applications. Water Res. 2013, 47, 2613-2632. [CrossRef] [PubMed]

102. Zhu, X.; Zhou, J.; Cai, Z. TiO2 nanoparticles in the marine environment: Impact on the toxicity of tributyltin to abalone (Haliotis diversicolor supertexta) embryos. Environ. Sci. Technol. 2011, 45, 3753-3758. [CrossRef] [PubMed]

103. D'Agata, A.; Fasulo, S.; Dallas, L.J.; Fisher, A.S.; Maisano, M.; Readman, J.W.; Jha, A.N. Enhanced toxicity of 'bulk' titanium dioxide compared to 'fresh' and 'aged'nano- $\mathrm{TiO}_{2}$ in marine mussels (Mytilus galloprovincialis). Nanotoxicology 2014, 8, 549-558. [CrossRef] [PubMed]

104. Nigro, M.; Bernardeschi, M.; Costagliola, D.; Della Torre, C.; Frenzilli, G.; Guidi, P.; Lucchesi, P.; Mottola, F.; Santonastaso, M.; Scarcelli, V. n- $-\mathrm{TiO}_{2}$ and $\mathrm{CdCl}_{2}$ co-exposure to titanium dioxide nanoparticles and cadmium: Genomic, DNA and chromosomal damage evaluation in the marine fish European sea bass (Dicentrarchus labrax). Aquat. Toxicol. 2015, 168, 72-77. [CrossRef] [PubMed]

105. Frenzilli, G.; Bernardeschi, M.; Guidi, P.; Scarcelli, V.; Lucchesi, P.; Marsili, L.; Fossi, M.C.; Brunelli, A.; Pojana, G.; Marcomini, A. Effects of in vitro exposure to titanium dioxide on DNA integrity of bottlenose dolphin (Tursiops truncatus) fibroblasts and leukocytes. Mar. Environ. Res. 2014, 100, 68-73. [CrossRef]

106. Nogueira, V.; Lopes, I.; Rocha-Santos, T.; Rasteiro, M.; Abrantes, N.; Gonçalves, F.; Soares, A.; Duarte, A.; Pereira, R. Assessing the ecotoxicity of metal nano-oxides with potential for wastewater treatment. Environ. Sci. Pollut. Res. 2015, 22, 13212-13224. [CrossRef] [PubMed]

107. Prosposito, P.; Burratti, L.; Bellingeri, A.; Protano, G.; Faleri, C.; Corsi, I.; Battocchio, C.; Iucci, G.; Tortora, L.; Secchi, V. Bifunctionalized silver nanoparticles as $\mathrm{Hg}^{2+}$ plasmonic sensor in water: Synthesis, characterizations, and ecosafety. Nanomaterials 2019, 9, 1353. [CrossRef]

108. Gliga, A.; Skoglund, S.; Wallinder, I.; Fadeel, B.; Karlsson, H. Size-dependent cytotocicity of silver nanoparticles in human lung cells: The role of cellular uptake, agglomeration and Ag release. Part. Fibre Toxicol. 2014, 11, 11-28. [CrossRef]

109. Ivask, A.; Kurvet, I.; Kasemets, K.; Blinova, I.; Aruoja, V.; Suppi, S.; Vija, H.; Käkinen, A.; Titma, T.; Heinlaan, M. Size-dependent toxicity of silver nanoparticles to bacteria, yeast, algae, crustaceans and mammalian cells in vitro. PLoS ONE 2014, 9, e102108.

110. Navarro, E.; Wagner, B.; Odzak, N.; Sigg, L.; Behra, R. Effects of differently coated silver nanoparticles on the photosynthesis of Chlamydomonas reinhardtii. Environ. Sci. Technol. 2015, 49, 8041-8047. [CrossRef] [PubMed]

111. Ribeiro, F.; Gallego-Urrea, J.A.; Jurkschat, K.; Crossley, A.; Hassellöv, M.; Taylor, C.; Soares, A.M.; Loureiro, S. Silver nanoparticles and silver nitrate induce high toxicity to Pseudokirchneriella subcapitata, Daphnia magna and Danio rerio. Sci. Total Environ. 2014, 466, 232-241. [CrossRef]

112. Sendra, M.; Yeste, M.P.; Gatica, J.M.; Moreno-Garrido, I.; Blasco, J. Direct and indirect effects of silver nanoparticles on freshwater and marine microalgae (Chlamydomonas reinhardtii and Phaeodactylum tricornutum). Chemosphere 2017, 179, 279-289. [CrossRef] [PubMed]

113. Chen, R.-J.; Chen, Y.-Y.; Liao, M.-Y.; Lee, Y.-H.; Chen, Z.-Y.; Yan, S.-J.; Yeh, Y.-L.; Yang, L.-X.; Lee, Y.-L.; Wu, Y.-H. The current understanding of autophagy in nanomaterial toxicity and its implementation in safety assessment-related alternative testing strategies. Int. J. Mol. Sci. 2020, 21, 2387. [CrossRef] [PubMed]

114. Lagadic, L. Biomarkers: Useful tools for the monitoring of aquatic environments. Rev. Med. Vet. 2002, 153, 581-588.

115. Arisaka, M.; Watanabe, M.; Ishizaki, M.; Kurihara, M.; Chen, R.; Tanaka, H. Cesium adsorption ability and stability of metal hexacyanoferrates irradiated with gamma rays. J. Radioanal. Nucl. Chem. 2015, 303, 1543-1547. [CrossRef]

116. Pshinko, G.; Puzyrnaya, L.; Shunkov, V.; Kosorukov, A.; Demchenko, V.Y. Removal of cesium and strontium radionuclides from aqueous media by sorption onto magnetic potassium zinc hexacyanoferrate (II). Radiochemistry 2016, 58, 491-497. [CrossRef]

117. Torad, N.L.; Hu, M.; Imura, M.; Naito, M.; Yamauchi, Y. Large Cs adsorption capability of nanostructured Prussian Blue particles with high accessible surface areas. J. Mater. Chem. 2012, 22, 18261-18267. [CrossRef]

118. Huang, Y.; Keller, A.A. Design and application of magnetic-core composite nano/micro particles for environmental remediation. In Rational Design of Next-Generation Nanomaterials and Nanodevices for Water Applications; IWA Publishing: London, UK, 2016 ; p. 17.

119. Mirshahghassemi, S.; Lead, J.R. Oil recovery from water under environmentally relevant conditions using magnetic nanoparticles. Environ. Sci. Technol. 2015, 49, 11729-11736. [CrossRef]

120. Zhang, W.; Hu, S.; Yin, J.-J.; He, W.; Lu, W.; Ma, M.; Gu, N.; Zhang, Y. Prussian blue nanoparticles as multienzyme mimetics and reactive oxygen species scavengers. J. Am. Chem. Soc. 2016, 138, 5860-5865. [CrossRef]

121. Kroto, H.W.; Heath, J.R.; O’Brien, S.C.; Curl, R.F.; Smalley, R.E. C 60: Buckminsterfullerene. Nature 1985, 318, 162-163. [CrossRef] 
122. Xing, G.; Zhang, J.; Zhao, Y.; Tang, J.; Zhang, B.; Gao, X.; Yuan, H.; Qu, L.; Cao, W.; Chai, Z. Influences of structural properties on stability of fullerenols. J. Phys. Chem. 2004, 108, 11473-11479. [CrossRef] [PubMed]

123. Holt, J.K.; Park, H.G.; Wang, Y.; Stadermann, M.; Artyukhin, A.B.; Grigoropoulos, C.P.; Noy, A.; Bakajin, O. Fast mass transport through sub-2-nanometer carbon nanotubes. Science 2006, 312, 1034-1037. [CrossRef]

124. Thong, Z.; Han, G.; Cui, Y.; Gao, J.; Chung, T.-S.; Chan, S.Y.; Wei, S. Novel nanofiltration membranes consisting of a sulfonated pentablock copolymer rejection layer for heavy metal removal. Environ. Sci. Technol. 2014, 48, 13880-13887. [CrossRef]

125. Xu, P.; Wang, W.; Qian, X.; Wang, H.; Guo, C.; Li, N.; Xu, Z.; Teng, K.; Wang, Z. Positive charged PEI-TMC composite nanofiltration membrane for separation of $\mathrm{Li}^{+}$and $\mathrm{Mg}^{2+}$ from brine with high $\mathrm{Mg}^{2+} / \mathrm{Li}^{+}$ratio. Desalination 2019, 449, 57-68. [CrossRef]

126. Rashid, M.; Ralph, S.F. Carbon nanotube membranes: Synthesis, properties, and future filtration applications. Nanomaterials 2017, 7, 99. [CrossRef]

127. Gupta, V.K.; Saleh, T.A. Sorption of pollutants by porous carbon, carbon nanotubes and fullerene-an overview. Environ. Sci. Pollut. Res. 2013, 20, 2828-2843. [CrossRef] [PubMed]

128. Jernelöv, A. How to defend against future oil spills. Nature 2010, 466, 182-183. [CrossRef]

129. Farinmade, A.; Ojo, O.F.; Trout, J.; He, J.; John, V.; Blake, D.A.; Lvov, Y.M.; Zhang, D.; Nguyen, D.; Bose, A. Targeted and Stimulus-Responsive Delivery of Surfactant to the Oil-Water Interface for Applications in Oil Spill Remediation. ACS Appl. Mater. Interfaces 2019, 12, 1840-1849. [CrossRef]

130. Nyankson, E.; Olasehinde, O.; John, V.T.; Gupta, R.B. Surfactant-loaded halloysite clay nanotube dispersants for crude oil spill remediation. Ind. Eng. Chem. Res. 2015, 54, 9328-9341. [CrossRef]

131. Owoseni, O.; Nyankson, E.; Zhang, Y.; Adams, D.J.; He, J.; Spinu, L.; McPherson, G.L.; Bose, A.; Gupta, R.B.; John, V.T. Interfacial adsorption and surfactant release characteristics of magnetically functionalized halloysite nanotubes for responsive emulsions. $J$. Colloid Interface Sci. 2016, 463, 288-298. [CrossRef]

132. Hokkanen, M.J.; Lautala, S.; Shao, D.; Turpeinen, T.; Koivistoinen, J.; Ahlskog, M. On-chip purification via liquid immersion of arc-discharge synthesized multiwalled carbon nanotubes. Appl. Phys. A 2016, 122, 1-8. [CrossRef]

133. Li, X.; Xue, Y.; Zou, M.; Zhang, D.; Cao, A.; Duan, H. Direct oil recovery from saturated carbon nanotube sponges. ACS Appl. Mater. Interfaces 2016, 8, 12337-12343. [CrossRef] [PubMed]

134. Spellauge, M.; Loghin, F.-C.; Sotrop, J.; Domke, M.; Bobinger, M.; Abdellah, A.; Becherer, M.; Lugli, P.; Huber, H.P. Ultra-shortpulse laser ablation and modification of fully sprayed single walled carbon nanotube networks. Carbon 2018, 138, $234-242$. [CrossRef]

135. Gui, X.; Li, H.; Wang, K.; Wei, J.; Jia, Y.; Li, Z.; Fan, L.; Cao, A.; Zhu, H.; Wu, D. Recyclable carbon nanotube sponges for oil absorption. Acta Mater. 2011, 59, 4798-4804. [CrossRef]

136. Liang, L.; Liu, P.; Su, H.; Qian, H.; Ma, H. One-step fabrication of superhydrophobic sponge with magnetic controllable and flame-retardancy for oil removing and collecting. J. Appl. Polym. Sci. 2020, 137, 49353-49364. [CrossRef]

137. Qiu, L.; Zhang, R.; Zhang, Y.; Li, C.; Zhang, Q.; Zhou, Y. Superhydrophobic, mechanically flexible and recyclable reduced graphene oxide wrapped sponge for highly efficient oil/water separation. Front. Chem. Sci. Eng. 2018, 12, 390-399. [CrossRef]

138. Wu, Z.-Y.; Li, C.; Liang, H.-W.; Zhang, Y.-N.; Wang, X.; Chen, J.-F.; Yu, S.-H. Carbon nanofiber aerogels for emergent cleanup of oil spillage and chemical leakage under harsh conditions. Sci. Rep. 2014, 4, 1-6. [CrossRef]

139. Zhu, K.; Shang, Y.-Y.; Sun, P.-Z.; Li, Z.; Li, X.-M.; Wei, J.-Q.; Wang, K.-L.; Wu, D.-H.; Cao, A.-Y.; Zhu, H.-W. Oil spill cleanup from sea water by carbon nanotube sponges. Front. Mater. Sci. 2013, 7, 170-176. [CrossRef]

140. Xu, C.; Jiao, C.; Yao, R.; Lin, A.; Jiao, W. Adsorption and regeneration of expanded graphite modified by CTAB-KBr/H3PO4 for marine oil pollution. Environ. Pollut. 2018, 233, 194-200. [CrossRef] [PubMed]

141. Bessa, A.; Gonçalves, G.; Henriques, B.; Domingues, E.M.; Pereira, E.; Marques, P.A. Green Graphene-Chitosan Sorbent Materials for Mercury Water Remediation. Nanomaterials 2020, 10, 1474. [CrossRef] [PubMed]

142. Yousefi, N.; Lu, X.; Elimelech, M.; Tufenkji, N. Environmental performance of graphene-based 3D macrostructures. Nat. Nanotechnol. 2019, 14, 107-119. [CrossRef] [PubMed]

143. Corsi, I.; Winther-Nielsen, M.; Sethi, R.; Punta, C.; Della Torre, C.; Libralato, G.; Lofrano, G.; Sabatini, L.; Aiello, M.; Fiordi, L. Ecofriendly nanotechnologies and nanomaterials for environmental applications: Key issue and consensus recommendations for sustainable and ecosafe nanoremediation. Ecotoxicol. Environ. Saf. 2018, 154, 237-244. [CrossRef]

144. Gao, M.; Li, N.; Lu, W.; Chen, W. Role of cellulose fibers in enhancing photosensitized oxidation of basic green 1 with massive dyeing auxiliaries. Appl. Catal. B 2014, 147, 805-812. [CrossRef]

145. Ibrahim, K.; Naz, M.; Shukrullah, S.; Sulaiman, S.; Ghaffar, A.; AbdEl-Salam, N. Nitrogen pollution impact and Remediation through Low cost Starch Based Biodegradable polymers. Sci. Rep. 2020, 10, 5927. [CrossRef]

146. Krishnani, K.; Ayyappan, S. Heavy metals remediation of water using plants and lignocellulosic agrowastes. In Reviews of Environmental Contamination and Toxicology; Springer: New York, NY, USA, 2006; pp. 59-84.

147. Meng, Y.; Young, T.M.; Liu, P.; Contescu, C.I.; Huang, B.; Wang, S. Ultralight carbon aerogel from nanocellulose as a highly selective oil absorption material. Cellulose 2015, 22, 435-447. [CrossRef]

148. Simsek, S.; Ovando-Martínez, M.; Whitney, K.; Bello-Pérez, L.A. Effect of acetylation, oxidation and annealing on physicochemical properties of bean starch. Food Chem. 2012, 134, 1796-1803. [CrossRef] 
149. Morin-Crini, N.; Winterton, P.; Fourmentin, S.; Wilson, L.D.; Fenyvesi, E.; Crini, G. Water-insoluble $\beta$-cyclodextrinepichlorohydrin polymers for removal of pollutants from aqueous solutions by sorption processes using batch studies: A review of inclusion mechanisms. Prog. Polym. Sci. 2018, 78, 1-23. [CrossRef]

150. Zhao, F.; Repo, E.; Yin, D.; Meng, Y.; Jafari, S.; Sillanpää, M. EDTA-cross-linked $\beta$-cyclodextrin: An environmentally friendly bifunctional adsorbent for simultaneous adsorption of metals and cationic dyes. Environ. Sci. Technol. 2015, 49, 10570-10580. [CrossRef]

151. Shak, K.P.Y.; Pang, Y.L.; Mah, S.K. Nanocellulose: Recent advances and its prospects in environmental remediation. Beilstein, J. Nanotechnol. 2018, 9, 2479-2498. [CrossRef]

152. Kargarzadeh, H.; Ahmad, I.; Thomas, S.; Dufresne, A. Handbook of Nanocellulose and Cellulose Nanocomposites; Wiley Online Library: Hoboken, NJ, USA, 2017.

153. Thomas, B.; Raj, M.C.; Joy, J.; Moores, A.; Drisko, G.L.; Sanchez, C.m. Nanocellulose, a versatile green platform: From biosources to materials and their applications. Chem. Rev. 2018, 118, 11575-11625. [CrossRef]

154. Bondancia, T.J.; Mattoso, L.H.C.; Marconcini, J.M.; Farinas, C.S. A new approach to obtain cellulose nanocrystals and ethanol from eucalyptus cellulose pulp via the biochemical pathway. Biotechnol. Prog. 2017, 33, 1085-1095. [CrossRef]

155. Liu, C.; Li, B.; Du, H.; Lv, D.; Zhang, Y.; Yu, G.; Mu, X.; Peng, H. Properties of nanocellulose isolated from corncob residue using sulfuric acid, formic acid, oxidative and mechanical methods. Carbohydr. Polym. 2016, 151, 716-724. [CrossRef] [PubMed]

156. Pierre, G.; Punta, C.; Delattre, C.; Melone, L.; Dubessay, P.; Fiorati, A.; Pastori, N.; Galante, Y.M.; Michaud, P. TEMPO-mediated oxidation of polysaccharides: An ongoing story. Carbohydr. Polym. 2017, 165, 71-85. [CrossRef]

157. Guidi, P.; Bernardeschi, M.; Palumbo, M.; Genovese, M.; Scarcelli, V.; Fiorati, A.; Riva, L.; Punta, C.; Corsi, I.; Frenzilli, G. Suitability of a cellulose-based nanomaterial for the remediation of heavy metal contaminated freshwaters: A case-study showing the recovery of cadmium induced dna integrity loss, cell proliferation increase, nuclear morphology and chromosomal alterations on Dreissena polymorpha. Nanomaterials 2020, 10, 1837.

158. Riva, L.; Pastori, N.; Panozzo, A.; Antonelli, M.; Punta, C. Nanostructured Cellulose-Based Sorbent Materials for Water Decontamination from Organic Dyes. Nanomaterials 2020, 10, 1570. [CrossRef] [PubMed]

159. Korhonen, J.T.; Kettunen, M.; Ras, R.H.; Ikkala, O. Hydrophobic nanocellulose aerogels as floating, sustainable, reusable, and recyclable oil absorbents. ACS Appl. Mater. Interfaces 2011, 3, 1813-1816. [CrossRef]

160. Mahmoodi-Babolan, N.; Nematollahzadeh, A.; Heydari, A.; Merikhy, A. Bioinspired catecholamine/starch composites as superadsorbent for the environmental remediation. Int. J. Biol. Macromol. 2019, 125, 690-699. [CrossRef]

161. Okoli, C.P.; Adewuyi, G.O.; Zhang, Q.; Zhu, G.; Wang, C.; Guo, Q. Aqueous scavenging of polycyclic aromatic hydrocarbons using epichlorohydrin, 1, 6-hexamethylene diisocyanate and 4, 4-methylene diphenyl diisocyanate modified starch: Pollution remediation approach. Arab. J. Chem. 2019, 12, 2760-2773. [CrossRef]

162. Peng, N.; Hu, D.; Zeng, J.; Li, Y.; Liang, L.; Chang, C. Superabsorbent cellulose-clay nanocomposite hydrogels for highly efficient removal of dye in water. ACS Sustain. Chem. Eng. 2016, 4, 7217-7224. [CrossRef]

163. Gallo, A.; Tosti, E. Reproductive Processes of Marine Animals as Biomarker for Environmental Stress Impact. In Encyclopedia of Marine Biotechnology; Wiley: Hoboken, NJ, USA, 2020; pp. 3283-3298. 